\title{
Soil Conservation Issues in India
}

\author{
Ranjan Bhattacharyya ${ }^{1, *}$, Birendra Nath Ghosh ${ }^{2}$, Pradeep Dogra ${ }^{2}$, Prasanta Kumar Mishra ${ }^{2}$, \\ Priyabrata Santra ${ }^{3}$, Suresh Kumar ${ }^{3}$, Michael Augustine Fullen ${ }^{4}$, Uttam Kumar Mandal ${ }^{5}$, \\ Kokkuvayil Sankaranarayanan Anil ${ }^{6}$, Manickam Lalitha ${ }^{6}$, Dibyendu Sarkar ${ }^{7}$, \\ Dibyendu Mukhopadhyay ${ }^{8}$, Krishnendu Das ${ }^{9}$, Madan Pal ${ }^{1}$, Rajbir Yadav ${ }^{1}$, \\ Ved Prakash Chaudhary ${ }^{10}$ and Brajendra Parmar ${ }^{11}$ \\ 1 ICAR-Indian Agricultural Research Institute, New Delhi 110012, India; madanpal@yahoo.com (M.P.); \\ rajbiryadav@yahoo.com (R.Y.) \\ 2 ICAR-Indian Institute of Soil and Water Conservation, Dehradun 248195, India; \\ bnghosh62@rediffmail.com (B.N.G.); dogra.pradeep@gmail.com (P.D.); pkmbellary@gmail.com (P.K.M.) \\ 3 ICAR-Central Arid Zone Research Institute, Jodhpur Rajasthan 342003, India; \\ priyabrata.iitkgp@gmail.com (P.S.); sk_ecology@yahoo.co.in (S.K.) \\ 4 Faculty of Science and Engineering, The University of Wolverhampton, Wolverhampton WV1 1LY, UK; \\ m.fullen@wlv.ac.uk \\ 5 ICAR-Central Soil Salinity Research Institute, Regional Research Station, Canning Town, \\ West Bengal 743 329, India; uttam_icar@yahoo.com \\ 6 ICAR-National Bureau of Soil Survey and Land Use Planning, Bangalore Regional Center, Bangalore 560024, \\ India; anilsoils@yahoo.co.in (K.S.A.); mslalit@yahoo.co.in (M.L.) \\ 7 Bidhan Chandra Krishi Viswavidyalaya, Mohanpur, Nadia, West Bengal 741252, India; \\ dsarkar04@rediffmail.com \\ 8 Uttar Banga Krishi Viswavidyalaya, Cooch Behar 736165, India; dibsm107@gmail.com \\ 9 National Bureau of Soil Survey and Land Use Planning, Kolkata Regional Centre, Kolkata 700091, India; \\ das_krishnendu@hotmail.com \\ 10 ICAR-Indian Institute of Farming System Research, Modipuram 250110, India; vp_ch@yahoo.co.in \\ 11 ICAR-Indian Institute of Rice Research, Hyderabad 500030, India; birju1973@gmail.com \\ * Correspondence: ranjan_vpkas@yahoo.com; Tel.: +91-7838781447
}

Academic Editor: Marc A. Rosen

Received: 16 April 2016; Accepted: 30 May 2016; Published: 18 June 2016

\begin{abstract}
Despite years of study and substantial investment in remediation and prevention, soil erosion continues to be a major environmental problem with regard to land use in India and elsewhere around the world. Furthermore, changing climate and/or weather patterns are exacerbating the problem. Our objective was to review past and current soil conservation programmes in India to better understand how production-, environmental-, social-, economic- and policy-related issues have affected soil and water conservation and the incentives needed to address the most critical problems. We found that to achieve success in soil and water conservation policies, institutions and operations must be co-ordinated using a holistic approach. Watershed programmes have been shown to be one of the most effective strategies for bringing socio-economic change to different parts of India. Within both dryland and rainfed areas, watershed management has quietly revolutionized agriculture by aligning various sectors through technological soil and water conservation interventions and land-use diversification. Significant results associated with various watershed-scale soil and water conservation programmes and interventions that were effective for reducing land degradation and improving productivity in different parts of the country are discussed.
\end{abstract}

Keywords: soil erosion control; conservation agriculture; cover cropping; environmental issues; economic issues; social issues 


\section{Introduction}

Soil and water are critical natural resources that must be kept in harmony with the environment for agroecosystems to be sustainable. Geologic erosion by wind and water has created some of the world's most productive soils (e.g., the Indo-Gangetic Plains, Nile Delta and Loess Plateau in China), but accelerated erosion, induced by anthropogenic perturbations, has had drastic effects on ecosystem services and resulted in significant dissection and transformation of landscapes. This review examines integrated soil and water conservation practises, implemented at the catchment scale to balance plant nutrition and increase productivity, while maintaining soil health as well as surface- and ground-water quality.

\section{Soil Degradation at Work}

Soil degradation in India is a pervasive problem [1]. According to the Government's harmonized database, $\sim 120.7 \mathrm{M} \cdot \mathrm{ha}$ of land is degraded [2], $70 \%$ of which is due to water erosion. Other estimates of land degradation in India range from 53.28 Mha [3] to 187.80 Mha [4], depending upon the methods used. For example, Mandal and Sharda (2011) created a database on permissible limits of erosion for 29 Indian states, while [5] documented soil erosion risk by overlaying spatial soil erosion rates and soil loss tolerances for different states.

\subsection{Soil Degradation in the Indian Himalayas}

The Northwestern Himalayan (NWHR) region, which covers $\sim 33.13 \mathrm{M} \cdot$ ha, comprising of Jammu and Kashmir, Himachal Pradesh and Uttarakhand States, forms 10.1\% of national area, and supports $2.4 \%$ and $4 \%$ of the human and cattle population of the country, respectively. It exhibits diverse climates, topography, vegetation, ecology and land use patterns [6]. The extent of soil erosion due to water erosion varies across the country from $<5 \mathrm{t} \cdot \mathrm{ha}^{-1}$. year ${ }^{-1}$ for dense forest area to $>80 \mathrm{t} \cdot \mathrm{ha}^{-1}$. year ${ }^{-1}$ in the Shiwalik Region [7]. Recent estimates indicate that nearly $39 \%$ area of the Indian Himalayas has potential erosion rates of $>40 \mathrm{t} \cdot \mathrm{ha}^{-1} \cdot$ year $^{-1}$, which is alarmingly high.

Growing concerns over the deteriorating environment by stakeholders and others are linked with crucial cause-and-effect arguments related to deforestation, landslides, large-scale downstream flooding, increasing poverty and malnutrition. To address these objectives, various soil conservation technologies have been developed and watershed development programmes were launched in India since Independence, aimed at improving agricultural productivity, especially through soil and water conservation interventions (i.e. production through soil protection). The June 2013 flood and landslide induced disaster in Uttarakhand is an example of an extreme event probably related to climate change. The currently operational schemes of soil conservation and watershed management do not have adequate provision to address such severe erosion problems under projected climate change scenarios. Hence, efforts are in progress to accommodate these scenarios in watershed development programmes.

Soil erosion rates in the Northeastern Indian Himalayas (NEH) vary widely from $<5 \mathrm{t} \mathrm{ha}^{-1}$ to $>40 \mathrm{t} \cdot \mathrm{ha}^{-1}$. year ${ }^{-1}$. About $30,4.5,21.2,16.8$ and $13 \%$ of the area in the region fall under the very severe, very low, moderate and severe erosion classes, respectively. It is projected that $\sim 59 \%$ of total geographic area (TGA) of the region requires water erosion control.

Land degradation due to soil acidity is more severe in Indian hilly regions (14\% of TGA) than that of the country ( $3.7 \%$ of TGA). The extent of acid-affected soils is much more in NEH ( $29 \%$ of TGA) than that in NWH $(0.8 \%$ of TGA). Other than water erosion, chemical soil degradation occurs in the Indian Himalayas because of: (i) decreased soil organic matter (SOM) and soil biological activities; (ii) deterioration of soil physical properties, induced by decreased SOM; and (iii) decreased availability of the plant nutrients $[1,8]$. 


\subsection{Soil Degradation in the Indo-Gangetic Plains}

The Indo-Gangetic plains (IGP) in India consist of the Punjab, Haryana, Delhi and Union Territory Chandigarh, Uttar Pradesh, Bihar and parts of West Bengal. In this region, the major cause of land degradation is water erosion.

\subsubsection{Ground-Water Exploitation and Falling Water-Tables}

Large quantities of water are required to grow flooded rice. Traditional rice cultivation requires $\sim 1500 \mathrm{~mm}$ of water during a growing season. In addition, $\sim 50 \mathrm{~mm}$ of water is required to raise seedlings to the transplanting stage. However, the actual amount of water applied by farmers is much higher than the requirement, especially where rice is grown on light-textured soils in the IGP [9]. Ground-water contributes $60 \%-65 \%$ of the total irrigation requirement; while the remaining $35 \%-40 \%$ is met through canals [10]. The excess demand for water is being met through over-exploitation of ground-water, leading to falling water-tables. Thus, five decades of rice-wheat cropping caused considerable depletion of water resources in this region. In the Punjab alone, there is an annual shortage of $\sim 1.2$ Mha metres of water [11]. About $95 \%-98 \%$ of the area under rice-wheat in Haryana is irrigated.

The rapid expansion of the tube-well network in the upper IGP has led to the exploitation of low-quality ground-water aquifers for crop irrigation. The situation is alarming in the central districts of the Punjab, where about two-thirds of the total number of tube-wells in the State ( 1.28 million) are concentrated. The ground-water table in this region during 1993-2003 fell $\sim 0.55 \mathrm{~m} \cdot$ year $^{-1}$. In some areas of the upper IGP, the water-table is now falling at nearly $1 \mathrm{~m} \cdot$ year $^{-1}$ [12]. The areas that have a water table deeper than $9 \mathrm{~m}$ increased from 3\% in 1973 to $90 \%$ in 2004 and almost 100\% in 2010 [13]. The water-table in $>70 \%$ of the area has now gone down to $\geqslant 21 \mathrm{~m}$. This is the result of an increasing number of submersibles, as the centrifuge pumps are no longer effective in pumping water. The costs of installing tube-wells and the electricity consumption to pump water have increased several-fold. About $30 \%$ of the total electricity in the State is being used for pumping water for irrigation. A recent study by NASA (National Aeronautics and Space Administration, Washington, DC, USA) suggested that $13-17 \mathrm{~km}^{3}$ of ground-water is lost permanently every year from the aquifers in the northwestern plains of the Punjab, Haryana, and western Uttar Pradesh [14].

\subsubsection{Declining Soil Health}

The rice-wheat system has resulted in the mining of major nutrients (nitrogen $(\mathrm{N})$, phosphorus $(\mathrm{P})$, potassium (K), and sulphur (S)) from the soil, leading to nutrient imbalances and the deterioration of soil quality. One $\mathrm{Mg}$ wheat removes 24.5, 3.8 and $27.3 \mathrm{~kg} \mathrm{~N}, \mathrm{P}$ and $\mathrm{K}$, respectively [15]. SOM contents are being consistently depleted in the IGP [16-18]. The problem of soil organic carbon (SOC) loss is exacerbated in areas suffering accelerated erosion by water $[19,20]$.

\subsubsection{Burning of Crop Residues}

The rice-wheat system accounts for $\sim 25 \%$ of the total crop residues produced in India [21]. Traditionally, rice and wheat straw (other than that used as dry fodder) and residues of other crops are used as livestock bedding, thatching material for housing, and fuel, but these form only a small portion of the total quantity of crop residues produced by the system. The remaining rice and wheat stubble are mainly burned or rarely incorporated after crop harvest [22]. There is an increasing trend of harvesting of rice and wheat through combines, leading to the production of an enormous quantity of crop residues. In rice-wheat cropping, the residues amount to $7-10 \mathrm{Mg} \cdot \mathrm{ha}^{-1} \cdot$ year $^{-1}$ [23]. According to a survey, $91 \%$ of rice areas and $82 \%$ of wheat areas in the Punjab are harvested by combine harvester [24], annually producing $\sim 37$ million $\mathrm{Mg}$ of crop residues. This practise is increasing in other regions of India where rice-wheat cropping is practised. With the increasing trend of combine harvesting, disposal of crop residues (especially rice residues) has become a major problem. Composting of 
these crop residues is not feasible due to many factors such as transportation costs, time required for composting and lack of feasible technique for rapid in situ composting.

In the Punjab, $\sim 40 \%$ rice and wheat residues are being burned in situ annually, leading to $\sim 5$ million $\mathrm{Mg} \mathrm{C}$ loss [25]. One $\mathrm{Mg}$ of wheat residue contains $4.8 \mathrm{~kg} \mathrm{~N}, 0.7 \mathrm{~kg} \mathrm{P}$ and $9.8 \mathrm{~kg} \mathrm{~K}$, whereas $1 \mathrm{Mg}$ of rice residues contains $6.1 \mathrm{~kg} \mathrm{~N}, 0.8 \mathrm{~kg} P$ and $11.4 \mathrm{~kg} \mathrm{~K} \mathrm{[26].} \mathrm{Burning} \mathrm{of} \mathrm{rice} \mathrm{straw} \mathrm{causes} \mathrm{gaseous}$ emission of $70 \% \mathrm{CO}_{2}, 7 \% \mathrm{CO}, 0.66 \% \mathrm{CH}_{4}$ and $2.09 \% \mathrm{~N}_{2} \mathrm{O}$ [27] and loss of $\leqslant 80 \% \mathrm{~N}, 25 \% \mathrm{P}, 21 \% \mathrm{~K}$ and $4 \%-60 \% \mathrm{~S}$ [28]. Thus, burning of crop residues threaten the health of both humans and ecosystems.

\subsection{Soil Degradation in Dry and Arid Regions}

Wind erosion affects $\sim 41 \%$ of global land area [29] and $~ 13.5 \%$ in India [4,30]. Wind erosion is very active in the Indian Thar Desert and poses severe multifaceted problems [31-34]. Loss of nutrient-rich particles from agricultural fields, suspension of fine particles in air, and deposition of eroded soil particles on railway tracks, roads, residential and commercial establishments (e.g., thermal power plants, gas and oil fields, water bodies and irrigation canals) are major wind erosion related problems in the region. During severe dust storm events, suspended particles may be transported several hundreds of kilometres and form a blanket of dust haze over the IGP and surrounding area. Prevailing weather and terrain conditions of this Desert are also very conducive to wind erosion. Among climatic factors, wind speed plays a vital role and, if it exceeds the threshold of $5 \mathrm{~m} \cdot \mathrm{s}^{-1}$ at $0.3 \mathrm{~m}$ height from the ground surface, it initiates wind erosion [35]. Among terrain properties, soil aggregate distribution, surface roughness, soil moisture and vegetation cover are important factors influencing wind erosion. Indiscriminate grazing in the region also further destroys vegetation and exposes the land surface, thus making it more vulnerable to wind erosion. Minute soil particles $(<60 \mu \mathrm{m})$ blown by wind is a major cause of particle air pollution and causes serious health hazards to both humans and livestock, not only within but also far beyond these areas [36]. Combating wind erosion in the vast desert requires prioritization of regions according to the severity of the problem. In the present document, it is aimed to provide details of different categories of wind erosion control measures as per the severity of the problems.

\subsection{Soil Degradation on Coastal Lands in India}

The coastal agro-ecosystem of India occupies $~ 10.8$ Mha. The region has varied topographical and geomorphological features diverse climatic and soil conditions and many crops are being cultivated. Hence, agriculture is highly complex and risk-prone.

The most common agricultural problems in the coastal areas are lack of irrigation water, high concentration of salts in soil and water due to coastal influences, high sea surges following the frequently occurring cyclones and super-cyclones and, occasionally, tsunami. Many coastal areas, particularly, the delta regions of the major rivers (i.e. the Ganges, Cauvery, Mahanadi and Krishna rivers) and numerous other minor rivers have additional problems of high drainage congestion, due to the presence of brackish ground-water at very shallow depth and poor hydraulic conductivity of soil due to heavy texture. The problem becomes very severe when there are high and skewed rainfall distributions, which is common in many parts of coastal India. The major problems associated with crop cultivation in the region are: high soil salinity, lack of good quality irrigation water in dry months, the presence of brackish ground-water tables at very shallow depth, high drainage congestion, the low-lying situation of most cultivated land, high and intensive rains during the monsoon months resulting in deep water-logging of cultivated fields and frequent cyclonic storms along with heavy rains causing damage to both rice and upland crops. These problems result in almost the entire region being mono-cropped to rice during the Kharif season.

Areas in the east and south-west receive high rainfall totals, whereas most tracts in Gujarat receive very low rainfall amounts. Regions such as Sundarbans suffer from excess water in the monsoon season, with problems of prolonged deep water-logged land. The salt affected soils occupy an extensive area spread over both east and west coast regions, and include saline, sodic, acid sulphate, marshy and 
water-logged subgroups situated in the low-lying areas [37]. Soil salinity hampers crop production in coastal ecosystems to such an extent that the term "coastal saline soil" has become almost synonymous, although incorrectly, with the entire coastal ecosystem. Impeded drainage, inundation and sea-water ingress have led to the development of saline and alkali soils, rendering vast land as tracts of Khar and Pokkali lands unsuitable for economic cultivation of the major crops. However, soil salinity in coastal regions is temporally variable. There is a gradual increase in soil salinity after the rainy season until the onset of the next monsoon season, due to upward capillary movement of saline ground-water. During the rainy season, most of the lands turn non-saline as soil salinity markedly decreases, due to leaching and washing of salts via rain-water.

Crop failures due to acidification and salinization are common in the acid sulphate and tidal marshy areas of Kerala, West Bengal and the Andaman and Nicobar Islands. Acid sulphate soils with distinct characteristics of high acidity occur in the low-lying areas of Kerala, Sudarbans of West Bengal and the Andaman and Nicobar Islands and they usually have toxic concentrations of soluble Fe and Al. These soils mostly develop as a result of drainage of soils rich in pyrites $\left(\mathrm{FeS}_{2}\right)$ which, on oxidation, produce sulphuric acid in the presence of excess $\mathrm{SO}_{2}{ }^{-}$ions, and are very poor in available $\mathrm{P}$, but rich in organic matter.

\section{3. "Best Bet" Options for Soil Conservation}

Major soil and water conservation problems in various agro-climatic zones of India are reported by Pathak et al. [38] (Table 1). Key land degradation mitigation techniques in the agro-climatic zones of India are compiled by Bhattacharyya et al. [1]. Based on experiences from the various soil water conservation programmes and research station work in India, the soil and water conservation practises of different agro-climatic zones of India are identified (Table 2). The issues related to the "best bet" options in a particular region are discussed here.

Table 1. Soil and water conservation problems in various agroclimatic zones of India.

\begin{tabular}{|c|c|c|c|c|}
\hline Serial No. & Soil Conservation Region & Annual Rainfall (mm) & Important Areas & Major Problems \\
\hline 1 & $\begin{array}{l}\text { North Himalayan } \\
\text { (excluding cold desert) }\end{array}$ & 500-2000 & $\begin{array}{l}\text { Mountains, temperate arid, } \\
\text { semi-arid and sub-humid areas } \\
\text { of Jammu and Kashmir, hill } \\
\text { areas and Himachal Pradesh. }\end{array}$ & $\begin{array}{l}\text { Soil erosion along hill } \\
\text { slopes. }\end{array}$ \\
\hline 2 & North eastern Himalayan & $1500-2500$ & Northeastern hills & Shifting cultivation. \\
\hline 3 & $\begin{array}{l}\text { Indo-Gangetic alluvial } \\
\text { soils }\end{array}$ & 700-1000 & $\begin{array}{l}\text { Punjab, Haryana, parts of } \\
\text { northeastern Rajasthan, Uttar } \\
\text { Pradesh and Bihar, Rajasthan, } \\
\text { Gujarat. }\end{array}$ & $\begin{array}{l}\text { Sheet erosion, ravine } \\
\text { lands and floods. }\end{array}$ \\
\hline 4 & $\begin{array}{l}\text { Assam Valley and } \\
\text { Gangetic Delta }\end{array}$ & $1500-2500$ & $\begin{array}{l}\text { Assam, Tripura, North Bengal } \\
\text { and Gangetic Delta Plains, } \\
\text { parts of West Bengal. }\end{array}$ & $\begin{array}{l}\text { Gully and stream } \\
\text { bank erosion. }\end{array}$ \\
\hline 5 & Desert area & $150-500$ & $\begin{array}{l}\text { Western central Rajasthan, } \\
\text { parts of Haryana and Gujarat. }\end{array}$ & $\begin{array}{l}\text { Shifting sand dunes } \\
\text { and wind erosion. }\end{array}$ \\
\hline 6 & $\begin{array}{l}\text { Mixed red, black and } \\
\text { yellow soils }\end{array}$ & $600-700$ & $\begin{array}{l}\text { Districts of Rajasthan, and } \\
\text { Uttar Pradesh and northern } \\
\text { Madhya Pradesh. }\end{array}$ & Ravine. \\
\hline 7 & Black soils & $500-700$ & $\begin{array}{l}\text { South western Rajasthan, part } \\
\text { of Madhya Pradesh, } \\
\text { Maharashtra, Andhra Pradesh, } \\
\text { Karnataka and Tamil Nadu. }\end{array}$ & $\begin{array}{l}\text { Sheet erosion and lack } \\
\text { of ground-water } \\
\text { recharge. }\end{array}$ \\
\hline 8 & $\begin{array}{l}\text { Black soils (deep and } \\
\text { medium deep) }\end{array}$ & $800-1300$ & $\begin{array}{l}\text { Parts of Maharashtra, Madhya } \\
\text { Pradesh and Andhra Pradesh. }\end{array}$ & Excessive soil erosion. \\
\hline 9 & Eastern red soils & $1000-1500$ & $\begin{array}{l}\text { Bulk of West Bengal, Bihar, } \\
\text { Orissa and Eastern Madhya } \\
\text { Pradesh, Chattisgarh, and part } \\
\text { of Andhra Pradesh. }\end{array}$ & $\begin{array}{l}\text { Sheet and gully } \\
\text { erosion and improper } \\
\text { land management. }\end{array}$ \\
\hline
\end{tabular}


Table 1. Cont.

\begin{tabular}{ccclc}
\hline Serial No. & Soil Conservation Region & Annual Rainfall $(\mathbf{m m})$ & \multicolumn{1}{c}{ Important Areas } & Major Problems \\
\hline \multirow{2}{*}{10} & Southern red soils & $\sim 750$, in Kerala $\leqslant 2500$ & $\begin{array}{l}\text { Bulk of Tamil Nadu hills and } \\
\text { plains, Kerala, Karnataka, } \\
\text { Andhra Pradesh and parts of } \\
\text { Maharashtra. }\end{array}$ & $\begin{array}{l}\text { Sheet and gully } \\
\text { erosion. }\end{array}$ \\
\hline \multirow{2}{*}{11} & East-west coasts & $\begin{array}{c}\text { East coast } \sim 1000 \text { and rest } \\
\text { heavy rainfall }\end{array}$ & $\begin{array}{l}\text { East and West coast from } \\
\text { Orissa to Saurashtra. }\end{array}$ & $\begin{array}{l}\text { Coastal salinity and } \\
\text { soil erosion. }\end{array}$ \\
\hline
\end{tabular}
Source: Pathak et al. [38].

Table 2. Prioritized field based soil and water conservation measures for various rainfall zones of India.

\begin{tabular}{|c|c|c|c|}
\hline \multicolumn{4}{|c|}{ Seasonal Rainfall (mm) } \\
\hline$<500$ & $500-700$ & 750-1000 & $>1000$ \\
\hline $\begin{array}{l}\text { Contour cultivation with } \\
\text { conservation furrows }\end{array}$ & $\begin{array}{l}\text { Contour cultivation with } \\
\text { conservation furrows }\end{array}$ & $\begin{array}{l}\text { Broad-bed and Furrow(BBF) } \\
\text { (Vertisols) }\end{array}$ & BBF (Vertisols) \\
\hline $\begin{array}{l}\text { Ridging sowing across } \\
\text { slopes }\end{array}$ & Ridging & Conservation furrows & Field bunds \\
\hline Mulching & Sowing across slopes & Sowing across slopes & Vegetative bunds \\
\hline Scoops & Scoops & Tillage & Graded bunds \\
\hline Tied ridges & Tide ridges & Lack and spill drains & Level terrace \\
\hline Off-season tillage & Mulching & Small basins & \\
\hline $\begin{array}{l}\text { Inter-row water } \\
\text { harvesting system }\end{array}$ & Zingg terrace & Field bunds & \\
\hline Small basins & Off-season tillage & Vegetative bunds & \\
\hline Contour bunds & $\begin{array}{l}\text { BBF (broad bed and furrow } \\
\text { system) }\end{array}$ & Graded bunds & \\
\hline Field bunds & Inter-row water harvesting system & Nadi & \\
\hline \multirow[t]{4}{*}{ Khadin } & Small basins & Zingg terrace & \\
\hline & Modified contour bunds & & \\
\hline & Field bunds & & \\
\hline & Khadin & & \\
\hline
\end{tabular}

\section{1. "Best Bet" Optionsfor Soil Conservation in the Hilly Regions}

Different options in this region are listed in Table 3. These may be grouped under: a. Technologies for Watershed intervention: Controlling mass erosion.

Table 3. Present generation technologies for soil conservation/watershed intervention and adoption constraints in the Indian Himalayan Region (Source: Sharda et al. [39]).

\begin{tabular}{clc}
\hline No. & \multicolumn{1}{c}{ Title of Potential Technology and Cost (Rupees ha ${ }^{-1}$ ) } & \multicolumn{1}{c}{ Arable land (I-IV) (vegetative measure) } \\
\hline 1 & \multicolumn{1}{c}{ Conservation Bench Terrace 19,000. } \\
\hline 2 & $\begin{array}{l}\text { Maize + Cowpea Intercropping for Resource Conservation } \\
\text { and Higher Productivity } \\
\text { 17,000. }\end{array}$ & $\begin{array}{c}\text { Uttarakhand } \\
\text { Himachal Pradesh }\end{array}$ \\
\hline 3 & $\begin{array}{l}\text { Conservation Tillage Maximizing Productivity in Maize-Toria } \\
\text { Cropping System } \\
\text { 16,440. }\end{array}$ & Uttarakhand \\
\hline 4 & $\begin{array}{l}\text { Vegetative Barriers } \\
\text { Rs. 6.2 per m running length. }\end{array}$ & $\begin{array}{c}\text { Uttarakhand } \\
\text { Himachal Pradesh }\end{array}$ \\
\hline 5 & $\begin{array}{l}\text { Supplemental Irrigation form Harvested Rain-water for } \\
\text { Higher Crop Production in Shivalik Region }\end{array}$ & $\begin{array}{c}\text { Himachal Pradesh } \\
\text { Punjab }\end{array}$ \\
\hline
\end{tabular}


Table 3. Cont.

\begin{tabular}{|c|c|c|}
\hline No. & Title of Potential Technology and Cost (Rupees ha ${ }^{-1}$ ) & Region/State \\
\hline \multicolumn{3}{|c|}{ Agroforestry system (non-arable land) } \\
\hline 1 & $\begin{array}{l}\text { Aonla Based Land Use Systems for Degraded Shivaliks } \\
17,180 \text { with in situ bunding and 23,500 for new orchard. }\end{array}$ & $\begin{array}{l}\text { Himachal Pradesh } \\
\text { Punjab }\end{array}$ \\
\hline 2 & $\begin{array}{l}\text { Ber Based Agri-Horticultural Systems of Marginal Lands in } \\
\text { Shivaliks } \\
14,000 .\end{array}$ & $\begin{array}{l}\text { Himachal Pradesh } \\
\text { Punjab } \\
\text { Manipur } \\
\text { Meghalaya }\end{array}$ \\
\hline 3 & $\begin{array}{l}\text { Silvipastoral Systems for Wasteland Utilization in Foothills of } \\
\text { the Western Himalayas } \\
24,175 \text {. }\end{array}$ & Uttarakhand \\
\hline 4 & $\begin{array}{l}\text { Peach Based Agri-horticultural Practises for Utilization of } \\
\text { Marginal Lands } \\
\text { 30,180 (with in situ bunded plants), 36,280 with nursery } \\
\text { raised plants). }\end{array}$ & $\begin{array}{l}\text { Uttarakhand } \\
\text { Meghalaya }\end{array}$ \\
\hline \multicolumn{3}{|c|}{ Engineering/bio-engineering measures (non-arable land) } \\
\hline 1 & $\begin{array}{l}\text { Water Mill Based Integrated Farming System (IFS) for } \\
\text { North-western Himalayas } \\
70,000 / \text { unit. }\end{array}$ & $\begin{array}{l}\text { Uttarakhand } \\
\text { HP } \\
\text { J and K }\end{array}$ \\
\hline 2 & $\begin{array}{l}\text { Rehabilitation of Mine Spoils in Hilly Regions } \\
50,000 .\end{array}$ & $\begin{array}{l}\text { Uttarakhand } \\
\text { HP } \\
\text { J and K }\end{array}$ \\
\hline 3 & $\begin{array}{l}\text { Katta-Crate Technology: A Cost Effective Measure for } \\
\text { Rehabilitation of Torrents and Mine-spoil Areas } \\
\text { Cost: Rs.624/m³. }\end{array}$ & $\begin{array}{l}\text { Uttarakhand } \\
\text { HP } \\
\text { J and K }\end{array}$ \\
\hline 1 & $\begin{array}{l}\text { Geotextiles for Soil Conservation } \\
\text { Cost: Rs. } 27 / \mathrm{m}^{2} \text { (for jute geotextile) } \\
\text { Rs. } 53 / \mathrm{m}^{2} \text { (for coir geotextile). }\end{array}$ & $\begin{array}{c}\text { Uttarakhand } \\
\mathrm{HP} \\
\mathrm{J} \text { and } \mathrm{K}\end{array}$ \\
\hline 2 & $\begin{array}{l}\text { Bio-engineering in Torrents of Shiwaliks } \\
\text { Cost: Rs. } 3-10 \text { lakh } / \mathrm{km} \text {. }\end{array}$ & $\begin{array}{c}\text { Uttarakhand } \\
\text { HP } \\
\text { J and K }\end{array}$ \\
\hline
\end{tabular}

\subsubsection{Controlling Landslides/Landslips}

The major mass erosion problems in the Himalayan region are due to landslides/slips, mine- spoil failures and torrents. Usually, $10-20$ landslides/slips/year have been observed to occur on hill roads. Nearly $44,000 \mathrm{~km}$ hill roads in India have chronic problem of landslides. Major landslides on hill roads result in an annual loss of $>50,000$ man-hours and 5000 vehicle hours per km [40]. Mining in the Himalayan states covers $>25,000$ ha (mostly limestone mining), causing heavy degradation and sediment outflow. Some $2.7 \mathrm{M} \cdot$ ha are affected by river bank erosion in India [41]. In the Shiwalik Region, $\sim 1517 \mathrm{~km}^{2}$ area comes directly under the course of torrents (hilly rivers having flash floods) affecting $\sim 7500 \mathrm{~km}^{2}$ of adjoining area due to flash floods and sedimentation across the hill states of northwestern India and the Shiwaliks Hills of Uttar Pradesh, Haryana and the Punjab.

Soil losses of $\sim 320-4000 \mathrm{t} \cdot \mathrm{ha}^{-1}$. year ${ }^{-1}$ due to landslides and $\sim 550 \mathrm{t} \cdot \mathrm{ha}^{-1}$. year ${ }^{-1}$ in mine-spoil areas were effectively controlled by bioengineering technologies. These consist of a package of soil and water conservation measures developed by ICAR-IISWC, Dehradun, for treatment/rehabilitation of mass erosion affected areas [1]. The bioengineering measures need to be sufficiently robust to handle the high runoff and sediment flow expected from these areas.

\subsubsection{Controlling River Bank Erosion}

Flood damage is generally considered to be associated with river floodplains. Bioengineering technology is being developed at ICAR-IISWC, Dehradun, for treatment of torrents in the Shiwaliks, where mechanical measures have been used along with suitable vegetable species for bank protection and vegetative reinforcement of structures. Suitable species include Arundo donax (Narkul or Nada), Vitex negundo (Shimalu), Ipomoea (Besharam), Bamboo, Napier (Hathi Ghas) and Saccharum munja (Munj ghas). The cost-benefit cost ratio of river training works is $>1: 2.65$ [41]. 


\subsubsection{Extreme Rainfall Induced Disaster in Uttarakhand and Some Remedial Measures}

A disaster occurred in Uttarakhand due to extreme rainfall during 14-17 June 2013, resulting in huge loss to life and property. Under a joint initiative of National Agricultural Research System and Uttarakhand State Government, a survey was conducted to observe the damage to natural resources, which included the following [42]:

- The agricultural fields/habitations situated within the high flood level of rivers/streams were washed away and damage was evident on adjacent flooded lands.

- The intensity of damage was more in untreated watersheds compared to treated ones.

- Maximum mass erosion problem observed was due to landslides/slips, especially along roads. Landslides/slips were more frequent where no retaining walls or toe drains were provided and slopes were unvegetated.

- The drainage lines (Nalas/gullies) treated with proper bioengineering measures (gabion check dams), even when they were 20-30 years old, were little affected.

- The diversion drains constructed by some farmers (at their own initiative) for safe disposal of runoff water saved valuable agricultural land and crops.

- Degraded hillslopes and landslides/slips treated some 12 years earlier with geojute technology were stable and had a lush green vegetation cover.

- Erosion problem was minimal in areas with good agroforestry practises.

\subsubsection{Impacts of Watershed Development Programmes}

The watershed development projects in India are sponsored and implemented by the Government of India. Various state departments, non-governmental organizations (NGOs) and self-help groups (SHGs) assist these programmes. The "Drought-Prone Area Programme" (DPAP), "Desert Development Programme" (DDP), "National Watershed Development Project for Rainfed Areas" (NWDPRA), "Watershed Development in Shifting Cultivation Areas" (WDSCA) and the "Integrated Watershed Development Project" (IWDP) are some of the important development programmes.

The first generation watershed projects were designed for soil conservation. However, the second generation aimed at conserving degraded land areas [43,44]. The third-generation watershed projects were introduced that emphasized participatory approaches. The new approach focuses on raising crop productivity and improving livelihoods [45].

\subsubsection{Impacts of Watershed Management}

Development of rainfed areas in India is one of the prime concerns, as $\sim 60 \%$ of agriculture is rainfed. Watershed development programmes are often adopted as effective tools to address problems of rainfed areas. Macro-level evaluation of 636 micro-watersheds (100 to 1000 ha area) was performed through meta-analysis. The benefits of watershed programmes are: augmented income, rural employment generation (151 person days ha ${ }^{-1}$ ), increased crop yields and cropping intensity $(36 \%)$, decreased runoff $(45 \%)$ and soil loss $\left(1.1 \mathrm{t} \cdot \mathrm{ha}^{-1} \cdot\right.$ year $\left.^{-1}\right)$, augmented ground-water and decreased poverty) [41]. Watershed development programmes generated an average cost-benefit ratio $(\mathrm{C}: \mathrm{B})$ of $1: 2$ and $0.6 \%$ of watersheds failed in terms of returns on investment $(\mathrm{C}: \mathrm{B}$ ratio $<1)$. Some $32 \%$ of watersheds had a mean cost:benefit ratio of $>1: 2$, and $27 \%$ of watersheds yielded an internal rate of return (IRR) $>30 \%$ (Table 4). Community watersheds should be executed in drylands by adopting holistic, participatory and business-orientated approaches [46]. The recent technologies and interventions showed better impacts in terms of C:B ratios and IRR in the 700-1100 mm rainfall agro-ecoregions, but not in $<700 \mathrm{~mm}$ and $>1100 \mathrm{~mm}$ rainfall zones [43]. Thus, there is a need to find and adopt specific watershed development technologies for $<700$ and $>1100 \mathrm{~mm}$ rainfall zones [47]). Wani et al. [48] observed that low-cost water harvesting structures throughout upper catchments benefited more farmers than construction of masonry check-dams only in lower reaches of watersheds. 
Table 4. Benefits from the sample watersheds according to people's participation and income group.

\begin{tabular}{|c|c|c|c|c|c|}
\hline \multirow{2}{*}{ Indicator } & \multirow{2}{*}{ Particulars } & \multirow{2}{*}{ Unit } & \multicolumn{3}{|c|}{ People's Participation } \\
\hline & & & High & Medium & Low \\
\hline \multirow[t]{2}{*}{ Efficiency } & $\mathrm{C}: \mathrm{B}$ & ratio & 2.63 & 1.60 & 1.42 \\
\hline & IRR & $\%$ & 38.28 & 22.26 & 17.30 \\
\hline Equity & Employment & Person days $\mathrm{ha}^{-1} \cdot$ year $^{-1}$ & 165.17 & 118.73 & 105.42 \\
\hline \multirow[t]{6}{*}{ Sustainability } & Increase in irrigated area & $\%$ & 77.43 & 56.17 & 29.43 \\
\hline & Increase in cropping intensity & $\%$ & 44.60 & 24.96 & 32.03 \\
\hline & Runoff reduced & $\%$ & 43.24 & 40.41 & 69.00 \\
\hline & Soil loss reduced & $\mathrm{t} \cdot \mathrm{ha}^{-1} \cdot$ year $^{-1}$ & 1.18 & 1.10 & 0.87 \\
\hline & & & \multicolumn{3}{|c|}{ Per capita income of the region } \\
\hline & & & High & Medium & Low \\
\hline \multirow[t]{2}{*}{ Efficiency } & $\mathrm{C}: \mathrm{B}$ & ratio & 1.75 & 1.96 & 2.25 \\
\hline & IRR & $\%$ & 24.55 & 27.90 & 30.64 \\
\hline Equity & Employment & Person days ha ${ }^{-1} \cdot$ year $^{-1}$ & 91.05 & 159.70 & 164.30 \\
\hline \multirow[t]{4}{*}{ Sustainability } & Increase in irrigated area & $\%$ & 48.48 & 45.83 & 76.02 \\
\hline & Increase in cropping intensity & $\%$ & 31.40 & 34.09 & 43.75 \\
\hline & Runoff reduced & $\%$ & 43.21 & 43.27 & 49.32 \\
\hline & Soil loss reduced & $\mathrm{t} \cdot \mathrm{ha}^{-1} \cdot$ year $^{-1}$ & 1.18 & 1.10 & 0.87 \\
\hline
\end{tabular}

\section{2. "Best Bet" Options in the Deserts}

\subsubsection{Management and Control of Wind Erosion}

Wind erosion can be controlled by two major ways: either by decreasing soil erodibility or by reducing the erosive energy of wind, which can be achieved by erecting barriers. This can be done through the use of various conservation practises: (i) reduced field width; (ii) providing vegetative cover on soil surfaces; (iii) utilization of stable soil aggregates or clods for wind resistance; and (iv) constructing ridges on contours [49]. Basic principles to control wind erosion are reviewed by several researchers [50-52]. Fundamental design aspects of wind barrier or wind fences are depicted in Figure 1. The sheltered distance created by a barrier on the leeward side depends on its height $(\mathrm{H})$, length $(\mathrm{L})$ and porosity $(\beta)$. Optimum designing of barrier may lead to a sheltered distance (L) of 20-25H. Wind barriers of different porosities are presented in Figure 1, starting from a solid barrier (A) to highly porous barrier (F). Barrier types $\mathrm{C}$ and $\mathrm{D}$ represent mixtures of different porosities and may be created by different compositions of plant canopy, shrub and grass vegetation.

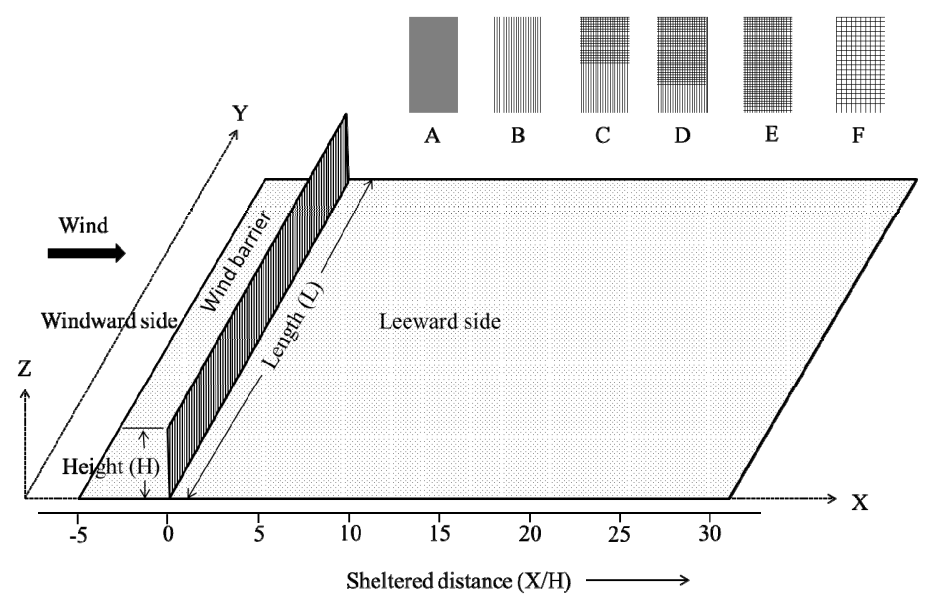

Figure 1. Design of wind barrier to control wind erosion.

Five major control measures include: (i) sand-dune stabilization, (ii) surface cover, (iii) wind breaks and shelterbelts; (iv) tillage; and (v) crop management (e.g., mixed cropping, intercropping and strip cropping systems). All these practises are designed to either absorb some of the wind energy and/or trap sediment. 


\subsubsection{Sand Dune Stabilization}

Much research effort has been devoted to wind erosion control in the Thar Desert of India [53-60]. Most of these studies reported sand-dune stabilization by vegetation cover using the checkerboard method, which became a popular wind erosion control technology in the region. Planting suitable vegetation on denuded dune surfaces decreases surface wind speeds, prevents scouring action and ameliorates soil conditions, which improves micro-climatic conditions. In view of the limited water, high percolation rates, high ambient temperatures and high potential evapo-transpiration rates in arid regions, it is important to select plants with the ecological ability to survive in such demanding situations. Of many criteria, the ones which require most attention in sand-dune stabilization are that those should be able to survive in: (i) extremes temperature conditions; (ii) a variety of salinity conditions; (iii) variable speed and direction of wind; (iv) severe sand storm events; (v) very low soil moisture conditions (i.e. xerophytes); and (vi) biotic stress situations.

\subsubsection{Surface Cover}

Use of surface cover to control wind erosion may be either vegetative or non-vegetative. Protection of the land surface through vegetative surface cover of grasses or crops is perhaps the most effective, easy and economical method. Grasslands of Lasuirus sindicus and Cenchrus ciliaris and maintenance of cover crops such as Citrullus colocynthis have major roles in decreasing wind erosion on sandy plains. In addition to the standing vegetation, crop residues are often placed artificially on the soil to provide temporary cover until establishment of permanent vegetation. Better wind erosion control may be obtained if residues are well anchored to the surface. Other than vegetative covers, various surface films were used for wind erosion control [61,62], mainly by decreasing soil erodibility.

The effectiveness of vegetative or non-vegetative covers depends on type of cover and several other factors. Permanent grass cover in rangelands is believed to be more effective than crop cover, which only exists in the field for short periods. Among crops, dense row crops and creeping crops are highly favourable. After plants complete their growth cycle, residues become the primary cover. The decay of leguminous residues is faster than of cereal or other crops and thus these are less durable and thus less effective in field conditions in terms of decreasing wind erosion. Moreover, more erect, finer and denser residues tend to decrease wind erosion. Maintenance of grass cover in rangelands is very important to control wind erosion and hence it is always better to adopt controlled grazing practises in rangelands, so as to maintain primary productivity and to provide sufficient protective grass cover. The aeolian mass transport rate was almost three-times more at the overgrazed site than at the controlled grazing site from mid-June to mid-July, as observed from a field study at two grazing situations in the Thar Desert [63].

\subsubsection{Wind Breaks and Shelterbelts}

Shelterbelts are barriers of trees or shrubs that are planted to decrease wind speed and thus, they have been consistently reported as effective barriers to prevent wind erosion and wind damage $[64,65]$. For shelterbelt establishment, design aspects were reported in detail by Mohammed et al. [66] and Cornelis and Gabriels [67]. Plant species of trees, shrubs and herbs to be used in shelterbelts need to be carefully selected, in terms of their height and canopy porosity, to maximize the shelter effect.

Maximum reductions in wind velocity by wind barriers occur at leeward locations, with a gradual increase downwind. In the case of rigid barriers, the percentage reduction remains constant for different wind speeds. However, in the case of flexible barriers (i.e. tree shelterbelts), the degree of wind erosion control is greater for low velocity winds than for high velocity winds. The direction of wind influences both the size and location of the leeward protected area. The area of protection is greater for wind blowing at right angles to the barrier length and is smallest or almost nil for wind blowing parallel with the barrier direction. The shape of windbreaks characterizes the outer perimeter or outer surface, which is in contact with the airstream. An abrupt vertical barrier is less effective than 
the sloped triangular outer surface. Therefore, tree shelterbelts with pyramidal cross sections will be more effective and such cross section may be obtained by planting tall trees in middle central rows followed by shrubs of two rows at the outer ends with decreasing height. Porosity is other important factor influencing the effectiveness of wind breaks. Dense barriers cause large decreases in wind speed, but for a short leeward distance; whereas porous barriers provide smaller decreases but for extended leeward distances [34,68-70]. Therefore, some porosity is always desirable. Barrier height is another important factor influencing barrier effectiveness. Expressed in multiples of barrier height $(\mathrm{H})$, the influence of a wind barrier may be $40-50 \mathrm{H}$ in the leeward direction.

Shelterbelt trees are generally planted at right angles to the prevailing wind direction. However, if wind direction changes frequently, a checkerboard pattern of plantings is required. Otherwise only parallel lines are needed. Two to five rows of fast growing trees of different heights should be planted to prevent any possible breaks in single rows, which would create a tunnelling action with high and potentially erosive wind velocities. Tree shelterbelts with different species composition suitable for the Thar Desert and their effect on wind speed reduction are reported by Mertia et al. [71] (Table 5).

Table 5. Design and species for shelterbelt plantation.

\begin{tabular}{ccl}
\hline Purpose & Design & \multicolumn{1}{c}{ Suitable Species } \\
\hline Road side & 3 to 5 staggered rows & $\begin{array}{l}\text { Acacia tortilis, Prosopisjuliflora, } \\
\text { Tamarixarticulate, Acacia nubica }\end{array}$ \\
\hline Railway side & 6 rows & Parkinsoniaaculeata, P. juliflora, T. articulata \\
\hline Canal side & rows & $\begin{array}{l}\text { Acacia nilotica, Eucalyptus spp., Tecomella. } \\
\text { undulata, } \text { A. tortilis, P. juliflora, D. sissoo, } \\
\text { P. cineraria }\end{array}$ \\
\hline Farm boundary (rainfed) & $1 / 2 / 3$ rows & $\begin{array}{l}\text { Acacia tortilis, A. lebbeck, A. indica, D. sissoo, } \\
\text { P. aculeata, P. juliflora, A. senegal }\end{array}$ \\
\hline Farm boundary (irrigated) & 2 rows & $\begin{array}{l}\text { A. tortilis, A. lebbeck, Dicrostachyscinerea, } \\
\text { P. juliflora }\end{array}$ \\
\hline
\end{tabular}

Source: modified from Mertia et al. [71] (2006).

Wind erosion in agricultural fields may also be controlled using micro-shelterbelts of high crops. In this method, a few rows of relatively tall crops (e.g., pearl millet (Pennisetum glaucum), sesame (Sesamum indicum) or castor (Ricinus communis) are sown 15-20 m from relatively short crops to provide them with shelter. Such short crops include mung bean (Vigna radiata), cluster bean (Cyamopsistetra gonoloba) and groundnuts (Arachishy pogaea).

\subsubsection{Tillage}

Tillage operations in arid lands control wind erosion mainly through creating rough surfaces and by bringing clay-rich subsoil to the surface and thus increasing the size and strength of clods. Normal tillage practises make ridges and furrows in the field and thus create rough surfaces. However, roughening the surface is effective only when the roughness elements are non-erodible clods. During tillage operations, it is always better to orient the ridge and furrow across the prevailing wind direction. Repeated or excessive tillage pulverizes the soil, which is more prone to erosion and hence should be avoided on drylands. The timing of tillage is also a very important factor, because soil water content during tillage operations strongly influences the degree of soil pulverization. More clods are produced if the soil is either extremely dry or extremely moist than if it is at intermediate moisture content. Emergency tillage or deep tillage to provide a rough cloddy surface is a temporary measure and is applied in extreme cases of vegetation depletion due to excessive grazing or drought. Emergency tillage should be accomplished at a depth which brings up compact clods, usually 10-15 $\mathrm{cm}$. If sufficient clay compacted clods are unavailable in the sub-soil, then it is recommended not to practise emergency tillage. 


\subsubsection{Crop Management}

Generally, crops grown at close spacing are more effective in controlling wind erosion than at wider spacing. The direction of crop rows with reference to prevailing wind direction has effects on wind erosion. It is recommended to align crop rows perpendicular to the prevailing erosive wind direction, to protect top-soils in inter-row areas from erosion.

\section{Issues Related to Conservation Options in Different Regions}

\subsection{Indo-Gangetic Plains}

\subsubsection{Conservation Agriculture}

Conservation agriculture (CA) is very popular in many parts of the globe. The key elements of conservation agriculture are: (i) minimum disturbance to soil; (ii) permanent soil cover; and (iii) the adoption of innovative and economically-viable cropping systems and rotations to decrease soil compaction [72,73]. CA offers opportunities for arresting and reversing soil degradation and decreasing cultivation costs. Conservation agricultural systems sequester carbon from the atmosphere, promote a healthy environment, improve biodiversity and biological processes.

\section{(1) Crop Yield Issues}

There are reports of higher crop yield following adoption of CA in IGP, particularly in the rice-wheat rotation (Tables 6 and 7). The increased wheat yield under CA is largely due to the time saved in land preparation (Table 8). Sowing time of wheat largely regulates yield as high temperature and delayed planting cause significant yield loss [74]. In the eastern IGP, where late sowing of wheat is quite common, productivity gains due to wheat planting advancement through adoption of zero tillage (ZT) can be $400-1000 \mathrm{~kg} \cdot \mathrm{ha}^{-1}$. The ZT system advances crop planting by at least a week, thereby decreasing yield losses by $1 \%-1.5 \%$ day $^{-1}$ after optimum wheat sowing time $[75,76]$. The challenges of continuous ZT practise are: management of perennial weeds and strategies for nutrient management to combat any yield decreases. In the initial years, yields of ZT crops are often decreased by $5 \%-10 \%$ on sandy loam soils in India, compared with conventional tillage [77].

Conservation agriculture integrates short-term concerns over productivity enhancement and also addresses long-term sustainability concerns. It is a concept for addressing location specificity of agricultural problems; it is not a technology per se. It is also not prescriptive in nature, but it is more knowledge intensive [78]. For instance, on sloping cultivated soils, use of grass buffer strips is very effective [41]. Along with grass buffer-strips, minimum tillage and use of organics decrease soil loss and increase productivity in a maize-wheat system on a $2 \%$ slope of the Indian Himalayas [8]. Conservation agriculture builds upon farmers' knowledge and experiences to manage production systems. It is a shift from a crop-based approach to a system-based approach (i.e. a farming system).

Smallholders basically depend on farm productivity that includes productivity from a wide range of crops and livestock. Hence, they adopt farming systems by default for their livelihood security. However, smallholder agriculture is constrained in many areas by poor soil quality, frequent droughts or excessive water, soil and water loss, poor crop productivity, inappropriate and often dysfunctional input-output markets and weak extension systems [78]. Thus, many rural households are malnourished, cannot improve their livelihoods and are food insecure. Hence, the integration of CA into smallholder farming systems is possibly the way forward to address prevailing constraints. Depending on the farming system, an integrated approach, which can support plant and animal productivity to restore soil quality, should be pursued. As CA requires a part of crop residues, extensive research is needed on the integration of CA and farming systems, focusing on the trade-offs for residue use under CA versus their other competitive uses in a specific farming system. 
Table 6. Effect of conservation agriculture-based technologies on crop yield, water saving and water productivity in the Indo-Gangetic Plains.

\begin{tabular}{|c|c|c|c|c|c|c|c|}
\hline Technologies & Location & Crop/Cropping & $\begin{array}{c}\text { Yield Gain } v s . \\
\text { Conventional } \\
\text { Agriculture }\left(\mathrm{kg} \cdot \mathrm{ha}^{-1}\right)\end{array}$ & $\begin{array}{l}\text { Water Saving } v s . \\
\text { Conventional } \\
\text { Agriculture (ha-cm) }\end{array}$ & $\begin{array}{l}\text { Increase in Water } \\
\text { Productivity } \\
\left(\mathrm{kg} \cdot \mathrm{m}^{-3}\right)\end{array}$ & $\begin{array}{c}\text { Net Return vs. } \\
\text { Conventional } \\
\text { Agriculture }\left(\$ \cdot \mathrm{ha}^{-1}\right)\end{array}$ & Reference \\
\hline \multirow{3}{*}{ Laser levelling } & Meerut & Rice-wheat & 750 & 26.5 & 0.06 & \multirow[t]{3}{*}{144} & [79] \\
\hline & Karnal & Rice-wheat & 810 & 24.5 & - & & [80] \\
\hline & Lidhiana & Rice & 750 & 22.0 & - & & [81] \\
\hline \multirow{3}{*}{ Zero-tillage } & Karnal & Wheat & $15-400$ & $2-4$ & $0.10-0.21$ & \multirow{3}{*}{$\begin{array}{c}15-24 \\
196\end{array}$} & [82] \\
\hline & Meerut & Wheat & 610 & 2.2 & 0.28 & & [83] \\
\hline & Delhi & Maize (Corn) & 150 & 8.0 & 0.21 & & [84] \\
\hline \multirow{3}{*}{$\begin{array}{l}\text { Zero-tillage with } \\
\text { residue mulch }\end{array}$} & Karnal & Rice-wheat & 500 & 61.0 & 0.24 & \multirow[b]{3}{*}{502} & [85] \\
\hline & Meerut & Wheat & 410 & 10.0 & 0.13 & & [86] \\
\hline & New Delhi & Cotton-wheat & 2540 & - & 0.26 & & [87] \\
\hline \multirow{3}{*}{ Direct seeded rice } & Ghaziabad & Rice & 120 & 25.0 & 0.08 & \multirow{3}{*}{-} & [88] \\
\hline & Ludhiana & Rice & 510 & 13.0 & 0.09 & & [89] \\
\hline & Karnal & Rice & 62 & 18.0 & 0.10 & & [90] \\
\hline \multirow{3}{*}{ Raised-bed planting } & Meerut & Maize (Corn) & 324 & 12.0 & 0.80 & \multirow{3}{*}{-} & [91] \\
\hline & Meerut & Wheat & 310 & 16.0 & 0.58 & & [92] \\
\hline & Kaithal & Wheat & 270 & 5.0 & 0.50 & & [93] \\
\hline
\end{tabular}


Table 7. Wheat grain yield in zero tillage and farmers' practise after puddle transplanted rice in the Indo-Gangetic Plains.

\begin{tabular}{|c|c|c|c|c|}
\hline \multirow{2}{*}{ Year } & \multirow{2}{*}{ Location } & \multirow{2}{*}{$\begin{array}{l}\text { Number of Farmers } \\
\text { Involved }\end{array}$} & \multicolumn{2}{|c|}{ Grain Yield $\left(\mathrm{kg} \cdot \mathrm{ha}^{-1}\right)$} \\
\hline & & & Zero-Tillage & Farmers' Practise $^{a}$ \\
\hline 1999-2000 & Haryana & 124 & 5380 & 5110 \\
\hline 2000-2003 & Eastern Uttar Pradesh & 357 & 3350 & 2980 \\
\hline 2001-2004 & Western Uttar Pradesh & 27 & 5120 & 4980 \\
\hline
\end{tabular}

Table 8. Zero tillage versus conventional tillage for growing wheat after rice in Haryana, India.

\begin{tabular}{cll}
\hline Parameters & \multicolumn{1}{c}{ Farmers' Perceptions } & \multicolumn{1}{c}{ Researchers' Findings } \\
\hline Sowing & $\begin{array}{l}\text { Wheat sowing } 5-14 \text { days earlier, } \\
\text { depending on size of farms }\end{array}$ & $\begin{array}{l}\text { Wheat sowing can be advanced by } \\
5-15 \text { days }\end{array}$ \\
\hline Fuel saving & Not available & Average 60 L diesel per ha \\
\hline Cost of cultivation & US \$42-92 ha ${ }^{-1}$ & US \$37-62 ha ${ }^{-1}$ \\
\hline Weed infestation & $20 \%$ less and weaker weeds & $43 \%$ less \\
\hline Irrigation & $\begin{array}{l}\text { Saves 30\%-50\% water in the first and } \\
15 \%-20 \% \text { in subsequent irrigations }\end{array}$ & $36 \%$ less water used \\
\hline Fertilizer use efficiency & High & High due to placement \\
\hline Wheat yield & $\begin{array}{l}\text { Higher, depending on days planted } \\
\text { earlier }\end{array}$ & 420-530 kg more per ha \\
\hline
\end{tabular}

(Source: Hobbs and Gupta [75]).

(2) Environmental Issues (Soil, Water and Atmosphere)

Conservation agriculture generally has the advantage of soil C-sequestration in diverse agro-ecosystems. ZT enhanced macro-aggregate-associated SOC and intra-aggregate particulate organic $C$ under a rainfed finger millet-lentil system, but only in the top-soil [80]. In the Indo-Gangetic Plains, top-soil under ZT with bed planting had greater macro-aggregates than conventional tillage with bed planting after four years [95].

Incorporation of organic residues initially leads to immobilization of inorganic $\mathrm{N}$, while addition of $15-20 \mathrm{~kg} \mathrm{~N} \mathrm{ha}^{-1}$ with residue incorporation increases rice and wheat yields. CA improves water use efficiency of crops by decreasing water loss. As ZT takes advantage of residual moisture from the previous crop, water use is decreased by $\sim 10 \mathrm{~cm} \cdot \mathrm{ha}^{-1}\left(\sim 1\right.$ million $\left.\mathrm{L} \cdot \mathrm{ha}^{-1} \cdot \mathrm{year}^{-1}\right)$. There was no yield advantage of growing crops on beds compared with flat areas under rice-wheat system on permanent beds, and there was little advantage in water savings [96-98].

In South Asia, ZT adoption in $5 \mathrm{M} \cdot$ ha could save $\sim 5 \times 10^{9} \mathrm{~m}^{3}$ water per annum. Such an amount may fill a $10 \mathrm{~km}$ long, $5 \mathrm{~km}$ wide and $100 \mathrm{~m}$ deep lake. Furthermore, the amount of saved diesel would be $\sim 0.5 \times 10^{6} \mathrm{~m}^{3}$ per annum [99]. This means an annual reduction of $1.3 \mathrm{M} \cdot \mathrm{t}$ in $\mathrm{CO}_{2}$ emissions. CA results in a better soil quality that favours larger yields [100] than traditional agricultural systems, which rely extensively on tillage, residue removal and monoculture. Less ploughing requires fewer tractors to burn smaller quantities of fossil fuels, thus decreasing $\mathrm{CO}_{2}$ emissions. Soils with better structure further reduce GHG emissions. Soils with higher SOM contents sequester more $\mathrm{C}$ and require less mineral $\mathrm{N}$. Where irrigation is available, moisture retention is improved. This means that fields require less irrigation, cutting fuel use for pumping water, with consequently reduced $\mathrm{CO}_{2}$ emissions.

(3) Economic Issues (Cost: Benefit Analysis of Technologies)

The factors to add savings in CA practises are: higher yield and reduced costs of cultivation (about half than that in the conventional cultivation). Areas under CA have increased globally, steadily from 2.8 Mha in 1973 to 117 Mha in 2010) [72]. However, distribution of CA adoption is skewed, due 
to lack of knowledge on the impacts of key CA components that affect crop productivity under diverse agro-ecological systems. Bottlenecks impeding CA adoption include:

- High initial expenditures of planting equipment.

- The completely new dimension and dynamics of a conservation farming system, which requires high management skills and a learning process.

- Risk of crop failure and decreased crop productivity in the initial years.

- New pest and disease problems.

- A shift in dynamics of dominant weed species and altered availability of $\mathrm{N}$, as some $\mathrm{N}$ may be locked up within soil aggregates due to better SOM availability. This leads to difficulties in fertilizer management, mainly in the residue-retained plots.

CA adoption is complex and depends on many factors. For the assessment of the performance of CA and their potential for widespread adoption, Corbeels et al. [101] used a framework that distinguishes the field, farm and village, and regional scales (Figure 2). They examined all scales and their interactions with emphasis on the most relevant factors to explain CA adoption or refusal. The performance of CA at the field scale is generally assessed through analysing crop productivity. However, it is clear that misleading conclusions can be drawn about the effectiveness of CA by only analysing crop yield responses at the field plot level. Other factors at different scales intervene. Given the fact that short-term profitability is a prime determinant, analysis of the farm-scale economics of CA can help assess the potential for CA adoption [102]. Farm-scale economics takes into account the trade-offs that may exist in the allocation of available resources (e.g., cash, labour, land and nutrients) to CA, which may in turn affect the performance and income of other farm activities.

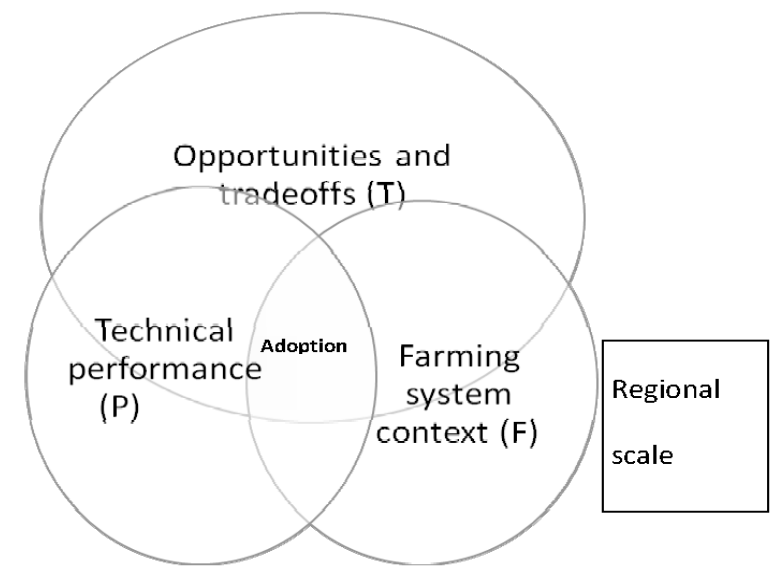

Figure 2. Adoption $=$ Performance + Trade-offs + Context $+(\mathrm{P} \times \mathrm{T} \times \mathrm{C})$ (Source: Corbeels et al [101]).

There are no set rules for CA, as all agro-ecosystems are different [78]. Resource-poor and vulnerable smallholders might face the greatest challenges in adopting the two key principles of CA, viz. (i) residue retention and (ii) diversified cropping. Crop residue retention is difficult due to strong competition for residues by livestock in mixed crop-livestock farms and other uses that yield additional farm income. Smallholders also often use maize, sorghum, mustard or millet stalks as a cooking fuel. Unavailability of resources, crop failure risks (mainly for vegetables and summer mung beans) due to climate change and the market-driven choice of cropping also create hindrances for diversified cropping systems.

(4) Social Issues

Availability of appropriate machinery to conduct CA demonstrations is the first major constraint. However, the other problems are convincing extension workers, farmers, and, initially, research 
scientists, that CA technology has many benefits. Farmers need to be demonstrated how CA works before they could be persuaded to accept this management practise. Once the seed germinated well, farmers usually ask to help them grow crops using CA. Now, ZT wheat is an acceptable technology. Similarly, other conservation practises, such as bed planting, will be accepted when appropriate machinery is available to farmers. A survey, conducted in 2000 in Haryana State, on 91 farmers in 20 villages showed that $24 \%$ of $\mathrm{ZT}$ adopters owned a tractor, while the rest used service providers. The average farm size of adopters ranged from 0.8 to 20.2 ha [78].

\section{(5) Policy Issues of Adoption of Conservation Agriculture}

The strategies, as mentioned below, can lead to widespread CA adoption and participatory research and demonstration should be flexible regarding testing and verifying CA. Modifications related to the stubble biomass (both amount and nature) and other organic residues to be left in the field, appropriate sowing time, nutrient management and integrated weed and pest management should be accomplished for each specific situation. Learning in principle is the first requirement for achieving acceptance of CA. This education should flow down from the agricultural research and extension systems to farmers with in-built mechanisms of feedback and experience of the farmers. Participating farmers must have access to suitable seeders. Farmers should use the zero-till seeders at no cost and should not bear any cost for its breakdown during their first time use. Once farmers and extension personnel understand and are willing to accept $C A$ in principle, they need to see it in practise. Policy should be implemented to manufacture new seeders and incentives may be given for buying new ones. This requires the collaboration of convinced scientists, extension workers, economists, policy-makers and farmers, as no one alone can do the job. Good quality economic analysis should be used more extensively to guide research and extension, particularly in relation to adaptation of CA based systems to suit local conditions [102].

\subsubsection{Watershed Management}

The Watershed Development Programme, one of the most popular development programmes in India, has been directed at the sustainable development of natural resources, soil and water conservation and the promotion of socio-economic development [103]. There are many visible impacts of these programmes across various regions.

\section{(1) Productivity Issues}

The quality of water harvesting structures of Tamil Nadu and Gujarat is good or very good. In the States of Madhya Pradesh, Uttar Pradesh, and Maharashtra, their quality is either average or good. However, in Jammu and Kashmir, the quality is poor. In most micro-watersheds in the States of Gujarat, Tamil Nadu, Uttar Pradesh, Madhya Pradesh and Rajasthan there is proof of decreased soil loss rates. Over 2/3 of micro-watersheds in Gujrat and Rajasthan have decreased soil erosion rates by $>50 \%$. Tamil Nadu, Madhya Pradesh and Uttar Pradesh have also achieved good results with $>25 \%$ lower soil erosion rates. Rates are also less in Karnataka, Himachal Pradesh, and Jammu and Kashmir.

Increased surface water is observed in most micro-watershed areas, of Rajasthan, Madhya Pradesh, Gujarat, Tamil Nadu, Karnataka Maharashtra, Nagaland and Assam. In 40\% of micro-watersheds in Gujarat, water-tables have risen by $>2 \mathrm{~m}$ due to watershed development programme implementation. This is the highest rise among Indian states.

Land use pattern changes positively in most watershed areas and programmes, such as the "Drought Prone Area Development Programme" (DPAP), “Desert Development Programme" (DDP) and "Integrated Watershed Development Programme" (IWDP) have shown positive trends, with more land coming under irrigation schemes. However, the main identified issue is that the people generally invest more in good class land and, therefore, inadequate attention is devoted to poor class land. Cropping systems are more intensive in Uttar Pradesh, Madhya Pradesh and Andhra Pradesh. In contrast, in Karnataka, Rajasthan and Tamil Nadu cropping intensity is less and no substantial increases 
have been observed [104]. Improved land use patterns have promoted agricultural intensification and thus increased agricultural production.

\section{(2) Socio-Economic Issues}

People's participation in watershed development programmes was usually unsatisfactory and there was an absence of formal institutional mechanisms in some places. In some states, no proper registers were maintained. Watershed development programmes have reduced women's workload by $1-2 \mathrm{~h}$, as collecting fuel-wood and fodder and fetching drinking water became easier. In Rajasthan and Tamil Nadu, workloads of women decreased considerably, but not in Himachal Pradesh and Jammu and Kashmir [104]. Various other benefits were noticed in many regions, such as reduced migration and female empowerment. However, the benefits were not maximized, due to social obstructions and female participation in community institutions remains limited.

\section{(3) Environmental Issues: Ground-Water Management}

For sustainable agricultural production in the Punjab, Haryana, and western Uttar Pradesh, major steps should be taken to improve ground-water management [11]. Ground-water management holds the key to the future sustainability of rice-wheat production in the region. The development of water-efficient cultivars and alternative methods of irrigation, as well as crop establishment methods that require less water, will be the deciding factors for future rice cultivation. The time has come to seriously consider the potential of rain-water harvesting.

\section{(4) Policy Issues}

Policy measures must be linked to both sustainable agriculture and environmental benefits. Several issues may be considered for funding from the Government of India [105]:

1. Decreasing use of agrochemicals and organic farming in suitable areas.

2. Decreasing stock density of sheep and/or cattle.

3. Using farm practises compatible with environmental protection and management of natural resources.

4. Involvement of elected representatives of the people (Members of the Legislative Assembly (MLAs) and Members of Parliament (MPs)) in the development process may assist decentralization of decision-making processes for better implementation of Government Plans [106].

Another important issue is allocation of costs and benefits. Watershed programmes should be implemented in such a way so that the benefits may be shared in accordance with the cost and contributions of participants. For instance, in the watershed framework, farmers based in the upper reaches have to invest more, but farmers in the lower or middle reaches gain from these actions [107]. Nevertheless, field-based soil and water conservation measures are essential for in situ soil conservation. Many field-based soil conservation measures have been found promising for the various rainfall zones in India and these are given in Table 2.

\subsection{Issues Related to Conservation Practices in Central India}

\subsubsection{Broad-Bed, Furrow System and Conservation Furrow System}

On black soils, water-logging and water scarcity normally occur during the same cropping season. Hence, in situ soil and water conservation and proper drainage technologies are required. The "broad-bed and furrow" (BBF) system has proved satisfactory for achieving these goals. Conservation furrows is a promising technology in red soils with moderate slopes $(0.2 \%-0.4 \%)$, receiving 500-600 mm rainfall. Black soils are mainly the swell-shrink and compact soils (Vertisols) in central India and red soils (Alfisols) are acidic, rich in iron (Fe) and aluminium (Al) oxides and 
are predominant in the Southern Peninsular region and Jharkhand and Orissa states. These two soil groups covere $\sim 150 \mathrm{M} \cdot$ ha.

(1) Crop Productivity Issues

In Vertisols of central India, the BBF system resulted in 35\% yield increase in soybean and 21\% yield advantage in chickpea after soybean, compared with farmers' practises [108]. Similar yield advantages were recorded in maize and wheat under the BBF system (Table 9).

Table 9. Effect of land configuration on productivity of soybean and maize-based system in the watersheds of Madhya Pradesh, 2001-2005 [108].

\begin{tabular}{|c|c|c|c|c|}
\hline \multirow{2}{*}{ Watershed Location } & \multirow[t]{2}{*}{ Crop } & \multicolumn{3}{|c|}{ Grain Yield $\left(t \cdot h^{-1}\right)$} \\
\hline & & Farmers' practise & BBF system & $\%$ Increase in Yield \\
\hline \multirow{2}{*}{ Vidisha and Guna } & Soybean & 1.27 & 1.72 & 35 \\
\hline & Chickpea & 0.80 & 1.01 & 21 \\
\hline \multirow{2}{*}{ Bhopal } & Maize & 2.81 & 3.65 & 30 \\
\hline & Wheat & 3.30 & 3.25 & 16 \\
\hline
\end{tabular}

Yield advantages, in terms of rainfall use efficiency (RUE), ranged from $10.9-11.6 \mathrm{~kg} \cdot \mathrm{ha}^{-1} \cdot \mathrm{mm}^{-1}$ under BBF systems (across various cropping systems) compared to $8.2-8.9 \mathrm{~kg} \cdot \mathrm{ha}^{-1} \mathrm{~mm}^{-1}$ with flat land in the grade system in Vertisols (Table 10). Yield advantages of $15 \%-20 \%$ were recorded in soybean, maize and groundnuts (Arachis hypogeae L.) with conservation furrows on Alfisols compared with farmers' practises in Karnataka State (Table 11).

Table 10. Rainfall use efficiency of different cropping systems under improved land management practises in Bhopal, Madhya Pradesh, India (Source: Singh et al. [108]).

\begin{tabular}{ccc}
\hline \multirow{2}{*}{ Cropping System } & \multicolumn{2}{c}{ Rainfall Use Efficiency $\mathbf{~} \mathbf{k g} \cdot \mathbf{h a}^{\mathbf{- 1}} \cdot \mathbf{~ m m}^{\mathbf{- 1}} \mathbf{)}$} \\
\cline { 2 - 3 } & Flat-on-Grade & Broad-Bed and Furrow \\
\hline Soybean-chickpea & 8.2 & 11.6 \\
Maize-chickpea & 8.9 & 11.6 \\
Soybean/Maize-chickpea & 8.9 & 10.9 \\
\hline \multicolumn{2}{c}{-denotes Sequential systems; / denotes Intercrop system. }
\end{tabular}

Table 11. Improved land and water management impacts on crop productivity in Sujala watersheds of Karnataka during 2006-2007 (Source: Singh et al. [108]).

\begin{tabular}{ccccc}
\hline & & \multicolumn{3}{c}{ Grain Yield (t. ha $^{-\mathbf{1}}$ ) } \\
\cline { 3 - 5 } Watershed & Cocation & Farmers' Practise & $\begin{array}{c}\text { Conservation } \\
\text { Furrows }\end{array}$ & $\begin{array}{c}\text { \% Increase in } \\
\text { Yield }\end{array}$ \\
\hline Haveri & Maize & 3.57 & 4.10 & 15 \\
Dharwad & Soybean & 1.50 & 1.80 & 20 \\
Kolar & Groundnut & 1.05 & 1.22 & 16 \\
Tumkur & Groundnut & 1.29 & 1.49 & 15 \\
\hline
\end{tabular}

\subsubsection{Contour Bunding}

Contour bunding is recommended for medium to low rainfall areas $(<700 \mathrm{~mm})$ and on permeable soils with $<6 \%$ slope. The bunds consist of series of narrow trapezoidal embankments along the contour. The bunds decrease runoff and hence promote runoff retention within fields. Contour bunded treatment recorded $0.3 \mathrm{t} /$ ha soil loss compared with $18.92 \mathrm{t} / \mathrm{ha}$ in control plots [109]. Similarly, runoff was $0.1 \mathrm{~mm}$ compared with $8 \mathrm{~mm}$ in the control [110]. Least runoff was observed in contour bunding supported by live bunding of subabul in Bangalore [111]. The increase in grain 
yield due to compartmental bunding, broadbed and furrows, and ridges and furrows was 43,38 and $35 \%$, respectively, compared with the flat bed system. Significantly more pigeonpea and sorghum grain yields were measured in intercropping systems with compartmental bunding than flat-bed cultivation [112].

The modified contour bunds with gated-outlets have good potential, because of better control of ponded water. An evaluation of the performance of conservation structures in the black soil area at Bijapur found that the development cost of structures, except contour ditches, was quickly repaid [113] (Table 12).

Table 12. Comparative studies on conservation measures at Bijapur, India (Source: Sharma et al. [114]).

\begin{tabular}{ccc}
\hline Conservation Structures & Cost: Benefit Ratio & Pay-Back Period (years) \\
\hline Contour bunding & 3.66 & 3 \\
Graded bunding & 5.62 & 1 \\
Broadbase bunds & 4.97 & 1 \\
Zingg terrace & 7.61 & 1 \\
Contour ditch & 2.09 & 5 \\
\hline
\end{tabular}

\subsubsection{Contour Farming}

Contour farming has considerable soil and water conservation potential. The seasonal runoff from the catchments decreased from $54 \%$ to $<40 \%$ of rainfall where contour farming was practised and the soil loss reduction was from $30 \mathrm{t} \cdot \mathrm{ha}^{-1}$ to $<20 \mathrm{t} \cdot \mathrm{ha}^{-1}$ [115]. Joseph and Manoj [116] summarized biological and engineering techniques used for conserving natural resources in red and black soils and reported $22.3 \%-65.5 \%$ increase in crop yield of rabi and kharif sorghum due to contour cultivation compared with up-and-down slope cultivation. Velayaudham et al. [117] conducted experiments during the north-east monsoon period to study the effects of in situ water harvesting measures on different crops under rainfed conditions. With contour ploughing, cowpea and castor were more profitable with C:B ratios of 1.9 and 1.86 , respectively.

\subsubsection{Vegetative Barriers}

Vegetation that can form a thick hedge established along contours can obstruct the flow of surface water. As a result, soil particles settle on the upstream side and filtered relatively clear water oozes through the barrier more uniformly across the field at decreased velocity. Trials on live hedge with khus (Vetiver) at Kabbalanala Watershed in Karnataka indicated high moisture availability in the root zone in plots with live hedge, resulting in higher crop yields compared to the control (Table 13). Mishra et al. [118] studied different vegetative barriers, including vetiver, napier, jatropha and agave, planted at $8 \mathrm{~m}$ intervals in the north-eastern Ghat zone of Odisha during 1994. Vetiver proved to be the most efficient vegetative barrier in conserving soil and water. It decreased runoff by $20.3 \%$ and soil loss by $51.4 \%$ and increased soil moisture storage by $26.6 \%$ compared with the control. Vetiver barriers on average reduced runoff by $19 \%$ and soil loss by $41 \%$, compared with no barriers as an inter-terrace treatment. Krishnegowda et al. [119] reported that the use of vegetative barriers as inter-terrace management markedly decreased soil losses. Soil erosion was $1.86 \mathrm{t} / \mathrm{ha}$ on the khus vegetated bund, $2.24 \mathrm{t} /$ ha on the Pennisetum hohenackeri bund and $3.2 \mathrm{t} / \mathrm{ha}$ on the control plot. Vegetative barriers decreased runoff and sediment loss in the order of kanna (Saccharum munja) $>$ napier $>$ bajra hybrid (Pennisetum purpureum) $>$ vetiver (Vetiveria zizanioides) $>$ babbar (Eulalioposis binata) $>$ without barrier [120]. When the purpose of the vegetative barrier is to act as a filter to trap eroded sediments, then appropriate grass species include vetiver, sewan (Lasiurus sindicus), sania (Crotolaria burhia) and kair (Capparis aphylla). However, if the purpose is to stabilize the bund, then Glyricidia is very effective that could provide $\sim 30-45 \mathrm{~kg} \mathrm{~N} \mathrm{ha}^{-1}$. year ${ }^{-1}$ as observed at the ICRISAT Research Centre, Hyderabad [121]. 
Table 13. Performance of different soil and moisture conservation structures.

\begin{tabular}{|c|c|c|c|c|c|c|c|}
\hline \multirow[t]{2}{*}{ Treatment } & \multirow[t]{2}{*}{ Runoff (\%) } & \multirow{2}{*}{$\begin{array}{l}\text { Soil Loss } \\
\left(\mathrm{t} \cdot \mathrm{ha}^{-1}\right)\end{array}$} & \multicolumn{4}{|c|}{$\begin{array}{c}\text { Soil Moisture }(w / w)(\%) \text { at } 0-15 \mathrm{~cm} \text { depth } \\
\text { in Standard Weeks }\end{array}$} & \multirow[t]{2}{*}{$\begin{array}{l}\text { Finger Millet } \\
\text { Yield }\left(\mathrm{q} / \mathrm{ha}^{-1}\right)\end{array}$} \\
\hline & & & 46 & 47 & 48 & 49 & \\
\hline $\begin{array}{l}\text { Control (along the } \\
\text { slope cultivation) }\end{array}$ & 26.30 & 11.01 & 7.69 & 3.85 & 3.68 & 3.35 & 18.60 \\
\hline $\begin{array}{c}\text { Existing bunds } \\
\text { (across major slope) }\end{array}$ & 20.10 & 7.36 & 9.09 & 6.49 & 3.74 & 3.62 & 19.30 \\
\hline Graded bunds & 10.62 & 3.71 & 10.13 & 7.59 & 4.58 & 3.81 & 24.12 \\
\hline Contour bunds & 3.80 & 1.30 & 11.84 & 8.00 & 5.76 & 4.32 & 24.25 \\
\hline Khus on contour & 7.90 & 2.48 & 11.39 & 7.85 & 5.68 & 4.18 & 24.75 \\
\hline
\end{tabular}

\subsubsection{Integrated Watershed Management}

Since rain-water conservation and utilization is the cornerstone of successful rainfed farming, watersheds with distinct hydrological boundaries are considered ideal for development. Past experiences of watershed projects implemented in rainfed regions have led to better water availability, due to additional surface storage and enhanced ground-water recharge. Increased water availability in wells and storage facilities has led to an increased cropping intensity by $50 \%$ over five years [122].

Soil and water conservation practises are the primary steps in integrated watershed management programmes. Impact analysis of watershed development projects showed that runoff from watersheds decreased by $9 \%-24 \%$ and soil loss by a mean of $72 \%$ [123]. Overall, the Crop Productivity Index (CPI) increased by $12 \%-45 \%$, with a mean increase in productivity of $28 \%$. The Crop Diversification Index (CDI) also increased by $6 \%-79 \%$, with a mean increase of $22 \%$ and the mean annual income per family increased by $43 \%$.

Some promising community-based soil conservation measures are: masonry check dams [124], low-cost earthen check dams and farm ponds (Figure 3). Water harvesting in these structures increases ground-water levels. Additional water resources are thus available to farmers in providing supplemental irrigation to crops (e.g., chickpeas or vegetables), especially after the rainy season. In most semi-arid tropical areas, farm ponds are usually unlined and therefore, much water is lost through seepage. On Vertisols, there is generally no need to line ponds, as seepage losses are usually low, mainly due to the very low saturated hydraulic conductivity in the range of $0.3-1.2 \mathrm{~mm} \cdot$ hour $^{-1}$ [125].

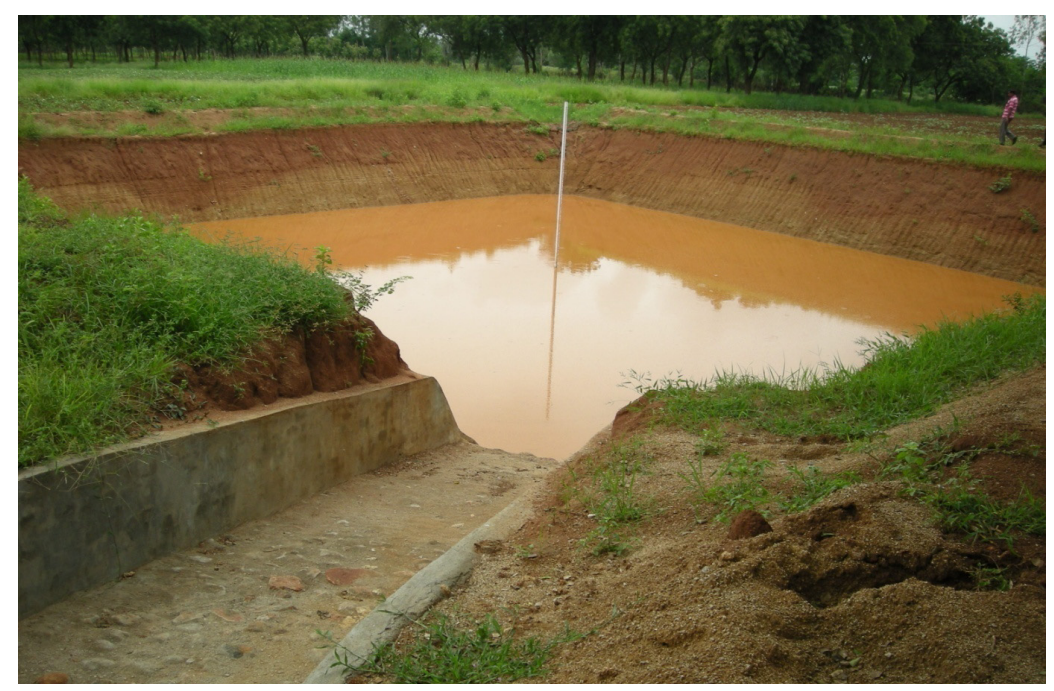

Figure 3. Farm pond for rain-water harvesting in Telengana, India. 
Other structures are: gully checks with loose boulder walls and sand bag structures. Gabions are wire-mesh baskets filled with stones (Figure 4). The wire-mesh holds the stones together and keeps them in place when the structure is subject to pressure. Gabions are effective at absorbing the kinetic energy of running water. A gabion is a semi-rigid, bulky mass, which is difficult for water to move. A row of linked gabions is fairly rigid and responds well to the terrain. These structures are used as checks in waterways and gullies.

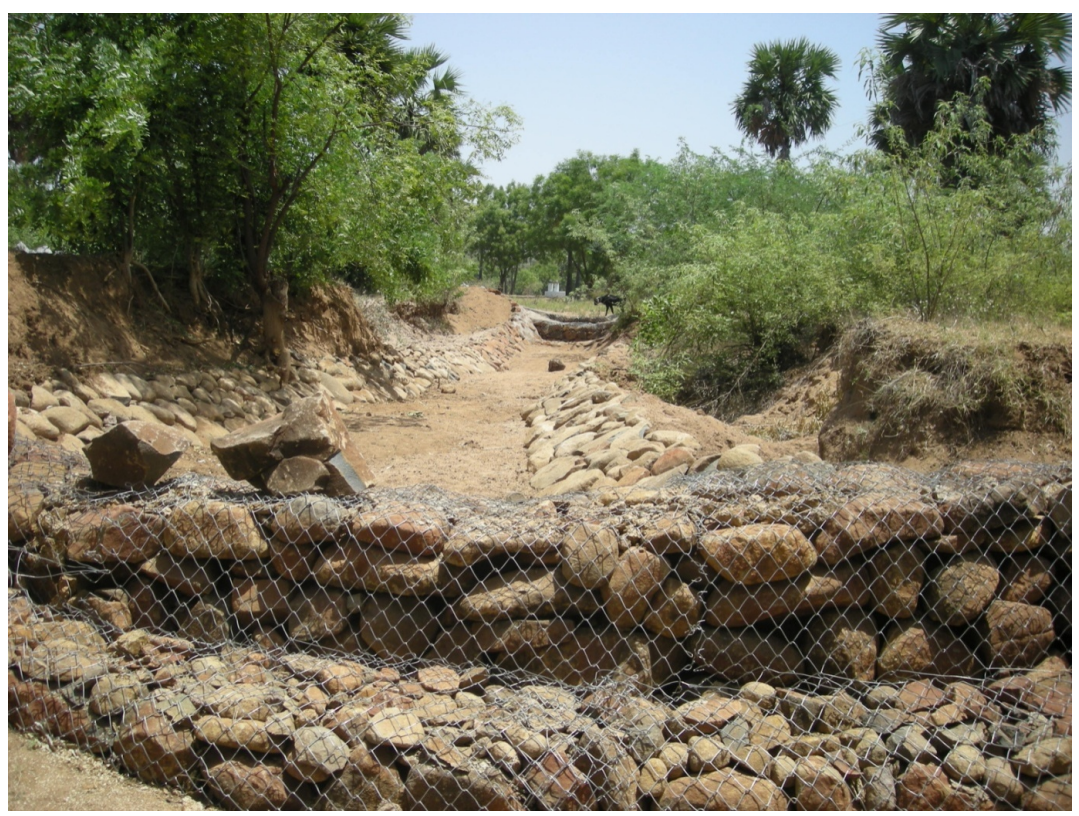

Figure 4. Stone pitching and stepped gabion for gully control in Telengana.

Sand bag structures are inexpensive temporary gully control structures made of empty fertilizers/cement bags filled with sand (Figure 5). They are mostly used in upper reaches of small gullies with relatively low runoff discharge and ample available sand. The empty cement bags are filled with sand and piled one above the other in rows, thus in-filling the gully. Whenever the sand bags are damaged they are replaced. Structures can be strengthened using a bio-energy approach, by supporting it with vegetation (Gliricidia) on the downstream side.

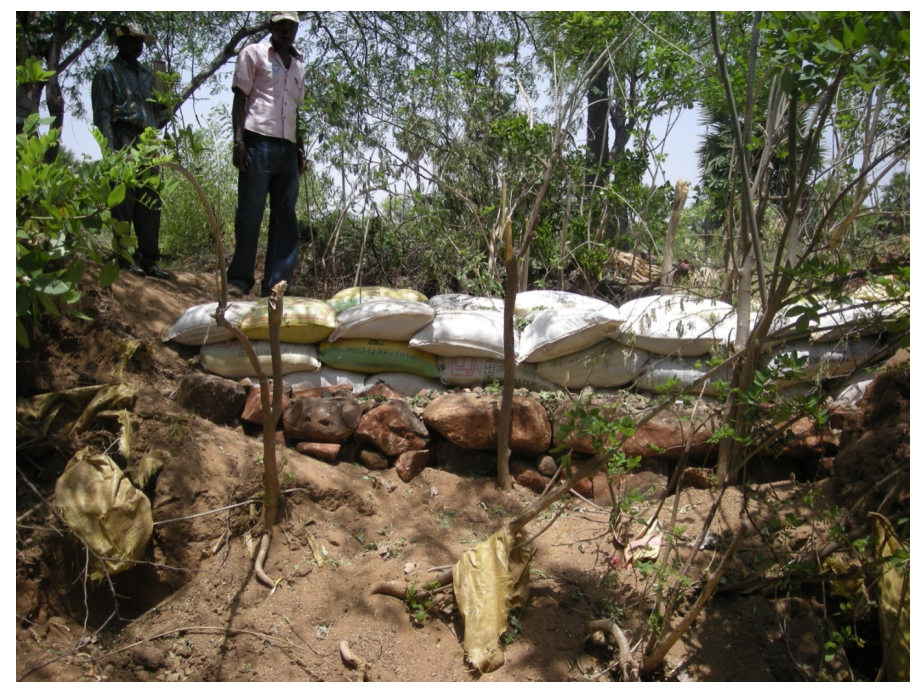

Figure 5. Sand bag structure for gully control in Telengana. 
Standardization of Design Parameters for Engineering Measures, including Rainfall-Runoff-Soil Loss Relationships

Rainfall-runoff-soil loss relationships are very important in designing erosion control measures. Knowledge and computation of peak runoff rates assists the cost-effective structural design of spillways. Information of the probability of the occurrence of various rainfall quantities and intensities, watershed characteristics and effect of watershed land-uses on runoff and erosion is essential. Rainfall characteristics in India have been studied by various workers [109]. Sharma and Tripathi [126] reviewed crop cover and management factors and reported that " $\mathrm{C}$ " varied from 0.22 (black gram at Dehradun) to 0.64 (sorghum at Hyderabad) for open-tilled intercrop and cover crops. The factor " $\mathrm{C}$ " is correlated with rainfall $\left(r^{2}=0.94\right)$. However, no such relationship exists for support practice " $\mathrm{P}$ ". Mishra and Sharma (1994) developed generic design criteria for dug-out farm ponds for minimizing evaporation and seepage losses.

Mandal and Sharda [127] estimated $85 \mathrm{Mg} \cdot \mathrm{ha}^{-1} \cdot$ year $^{-1}$ as potential soil loss in hilly areas in a watershed in the Telengana Region. Among the different land-use systems, the highest $\left(8.83 \mathrm{Mg} \cdot \mathrm{ha}^{-1} \cdot\right.$ year $\left.^{-1}\right)$ and the lowest $\left(0.36 \mathrm{Mg} \cdot \mathrm{ha}^{-1} \cdot \mathrm{year}^{-1}\right)$ soil erosion rates were calculated for fallow and fodder grassland, respectively. Similar ranges in soil erosion calculated using the USLE were also reported in the nearby Rangareddy District of Andhra Pradesh State [128]. Soil losses were lowest in the fodder grass area, because grass hedges acted as vegetative buffers that were effective in trapping sediment and thereby decreasing soil erosion.

The use of USLE model warrants knowledge of various parameters required for the model. Much work in India has been devoted to the determination of USLE parameters. The main limitation to the use of the USLE for computing sediment loss is the poor database. The "All India Soil and Land Use Survey (AISLUS)" has developed a Silt Yield Index Model, which is mostly used for prioritizing watershed selection. Much work in developing, validating and using various models in India, have very limited utility [129-131].

\subsection{Issues Related to Soil Conservation Options in Southern Peninsular India}

For each agro-climatic region of the country, the problems of soil and water conservation are different [10]. The major problems are listed in Table 14. Hence, unique soil water conservation measures were worked out for different regions based on identical soil, climatic and topographic conditions [38]. Hence, various field and community-based moisture conservation practises are emphasized for improving moisture [38] (Table 15) and increasing crop yields.

Table 14. Problems of soil and water conservation in different climatic regions of southern peninsular India (Source: Singh [10]).

\begin{tabular}{ccclc}
\hline Serial No. & Soil Conservation Region & Rainfall $(\mathbf{m m} /$ year) & Important Areas & Problems \\
\hline 1. & Black soils & $500-700$ & $\begin{array}{l}\text { Andhra Pradesh, } \\
\text { Karnataka and small } \\
\text { parts of Tamil Nadu }\end{array}$ & $\begin{array}{l}\text { Sheet erosion and acute } \\
\text { water shortage }\end{array}$ \\
\hline 2. & Black soil (deep and medium & Parts of Andhra Pradesh & $\begin{array}{l}\text { High soil erosion and } \\
\text { water-logging }\end{array}$ \\
\hline 3. & Eastern red soils & $800-1300$ & Part of Andhra Pradesh & $\begin{array}{l}\text { Sheet erosion, and } \\
\text { recurring drought }\end{array}$ \\
\hline 4. & Southern red soils & $1000-1500$ & $\begin{array}{l}\text { Kerala, Tamil Nadu, } \\
\text { Karnataka, Andhra } \\
\text { Pradesh and } \\
\text { Maharashtra }\end{array}$ & $\begin{array}{l}\text { Sheet erosion, gullies, } \\
\text { and lack of } \\
\text { ground-water recharge }\end{array}$ \\
\hline
\end{tabular}


Table 15. Soil and water conservation measures for different climatic regions of southern peninsular India (Source: Pathak et al. [38]).

\begin{tabular}{cll}
\hline Seasonal Rainfall $(\mathbf{m m})$ & \multicolumn{2}{c}{ Soil and Water Conservation Measures } \\
\hline$<500$ & $\begin{array}{l}\text { Contour cultivation with conservation } \\
\text { furrows, Mulching, Inter-row water } \\
\text { harvesting system }\end{array}$ & \begin{tabular}{l} 
Tied ridges, Contour bunds \\
\cline { 3 - 3 }
\end{tabular} - $\begin{array}{c}\text { Zingg terrace, Modified Contour bunds and } \\
\text { Broad bed furrow }\end{array}$ \\
\hline $750-1000$ & $\begin{array}{l}\text { Broad bed furrow, Field bunds, and } \\
\text { Graded bunds }\end{array}$ & $\begin{array}{l}\text { Conservation furrows, Lock and spill drains, } \\
\text { Small basins, }\end{array}$ \\
\cline { 3 - 3 } & Choes, Level terraces, Nadi and Zingg terrace \\
\hline$>1000$ &
\end{tabular}

\subsubsection{Productivity Issues}

Farmers normally benefit from short-term paid labouring work [132]. Hence, soil conservation works need regular repair and maintenance to remain effective. From the impact study of the SUJALA Watershed Project of the Government of Karnataka, it was evident that when conservation structures were used for productive purposes (e.g., farm pond-water for critical irrigation or vegetable production), the level of maintenance by farmers is good. However, in other areas where conservation structures do not increase crop production (e.g., gully control structures), the structures fall into disrepair [133]. There is also an increasing trend to produce higher-value cash crops, especially in those areas where conservation interventions have made evident increases in water availability. In Karnataka State, farmers are increasingly focusing on horticulture, vegetable cultivation, sericulture and changing crops (e.g., from the staple food crop ragi to maize). This is mainly due to the cost of cultivation and the prevailing market prices [132]. Drinking water problems indicate existing soil conservation interventions have not succeeded in decreasing drought [134]. Hence, conservation programmes should be location specific and control ground-water extraction. There is considerable temporal and spatial variability in crop productivity and the most promising case studies are during good or normal rainfall years, with poor crop yields in drought years [135]. Thus, farmer opinions are supportive in good years, but negative in drought years [136].

\subsubsection{Environmental Issues}

Soil conservation measures had positive impacts on environmental indicators in many areas. However, the increased availability of irrigation water often leads to declines in the importance of livestock, as grazing lands are converted to croplands. Thus, while substantial improvements are made in accessing water resources, this might lead to bringing marginal grazing lands unsuitable for cultivation into agricultural cultivation. This causes land degradation problems due to the unavailability of grazing lands [137]. In the case of employment generation and rural-to-urban migration, watershed development does have the potential to temporarily decrease migration [135]. However, in the post-project phase, trends vary and depend on many factors, such as caste, discrimination, wage differential and employment opportunities. The number of bore-wells and the depth of bore-wells have been increased two and three fold, respectively. Hence, ground-water has been exploited beyond its sustainable limits. In the Dodahalla Watershed of Karnataka, the extraction rate of ground-water in some villages is $2-5$ times higher than the average recharge values [138].

\subsubsection{Economic Issues}

One of the major shortcomings identified in the non-adoption of conservation technology by farmers within rainfed agriculture is the incompatibility of technology with their socio-economic conditions and risk-taking capacity. Thus, it is essential to identify packages of practises which give farmers the option to choose the level of technology suitable for their site, socio-economic conditions and risk-taking capacity [139]. The availability of green manure, fodder and firewood and timber for agricultural implements has considerably declined after the afforestation programme, attributed to changes in land-use resulting from common land under brushwood being cultivated [140]. 


\subsubsection{Social Issues}

Watershed development programmes are considered as an integrated and comprehensive location-specific action plan for rural areas and peoples' participation is essential for planning, implementation and maintenance. The evaluation of 15 watersheds managed through the "Drought Prone Area Programme" (DPAP) in the Coimbatore District of Tamil Nadu showed that community participation was medium, low and very low (viz. 55, 44 and 27\%), respectively, at planning, implementation and maintenance stages. Augmented productivity has been mainly restricted to those sections that could take advantage of or have access to the improved water resources [141].

\subsubsection{Political Issues}

The interface between the Panchayat Raj Institutions and Watershed Associations is not seen at all. This is because the members of the Watershed Associations believe that if the Panchayat Raj Institutions were given importance within the programme, the Watershed Associations would then become politicized. NGOs also consider that if Watershed Associations are made part of Panchayat Raj Institutions, the implementation of activities will be at the hands of political leaders. Watershed development funds must be utilized only for operation and maintenance of the assets created. However, it is perceived that the fund is not being utilized due to local political influences and so the flow of funds is irregular [142].

Water conservation activities have a significant impact on ground-water recharge, access to ground-water, improved crop yields and crop diversification. Therefore, our policy focus must be water harvesting structure, and farm pond development through public and private investments. Bench terracing is usually recommended for the hilly regions and requires initial heavy investment, which impedes technology uptake by many farmers. In the new Puerto Rican method of terrace formation, the expenditure incurred is only one-sixth of the cost of mechanical terracing. This method is a natural process in which the tilled soil moves towards the vegetative barrier and is deposited against it, leading to the formation of terraces in three-four years. This technology was developed by the Central Soil Water Conservation and Training Institute (Ooty) and was successfully adopted by farmers, as it is an economical and eco-friendly conservation measure [41].

\subsection{Soil and Water Conservation Issues in Coastal Regions}

\subsubsection{Soil and Water Conservation through Land Shaping Techniques in Coastal Regions}

Rain-water harvesting in farm pond with suitable land shaping (farm pond technique) was developed at CSSRI, Regional Research Station (RRS), Canning Town, West Bengal, under the leadership of Dr K.V.G.K. Rao during the 1980s. The technique improves the productivity of salt-affected coastal soils using integrated agriculture-aquaculture farming [143]. The research work in the Sundarbans Region showed that digging a farm pond in the $1 / 5$ th area of the farm pond and using the excavated soil for raising the remaining the land can facilitate the transformation of mono-cropped coastal land to multi-cropped land with diversified crops. Harvesting rain-water in farm ponds and raising lowland with excavated soil reduced the impact of the saline ground-water table on soil salinity. The technique also improved drainage from low-lying land and created irrigation resources for irrigation deficient coastal areas. The following land shaping models are popular in coastal regions of India.

Farm Pond: About $20 \%$ of the farm area is converted into on-farm pond of $\sim 3 \mathrm{~m}$ depth to harvest excess rain-water. The dug-out soil is used to raise the land to form high land/dike and medium land situations besides the original lowland situation in the farm for growing multiple and diversified crops throughout the year, instead of mono-cropping with rice in the kharif season. The upper land is free from water-logging in the kharif season, with less salinity accumulation in dry seasons and thus can be used for multiple and diversified crop cultivation throughout the year (Figure 6). 


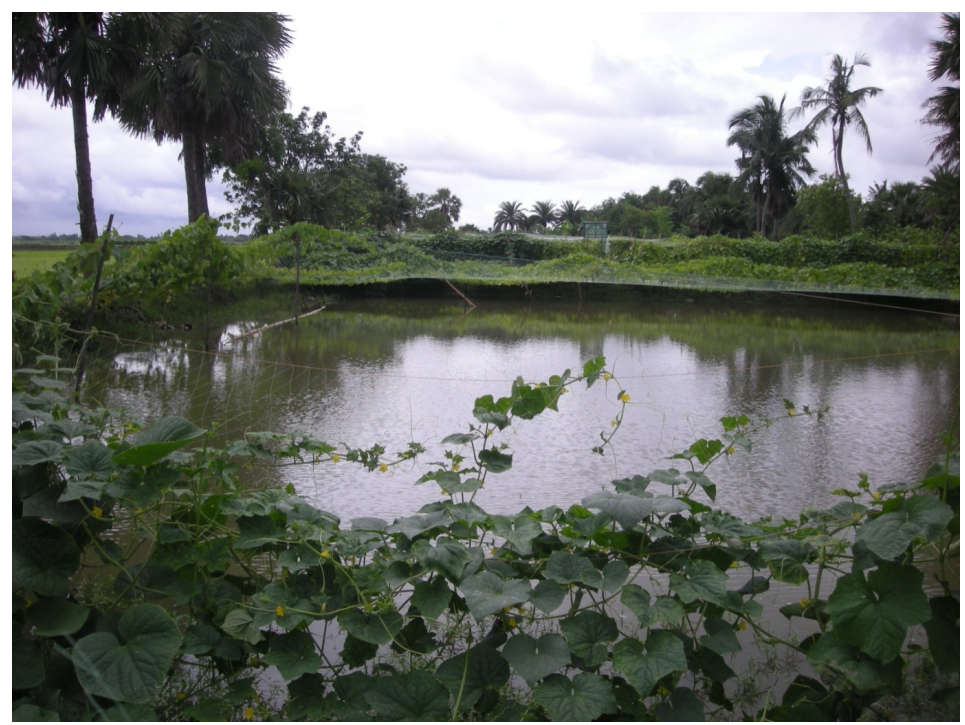

Figure 6. Farm pond technology in farmer's field in the Gangetic coastal region of West Bengal.

Deep furrow and high ridge: About $50 \%$ of farm land is shaped into alternate ridges (1.5 $\mathrm{m}$ top width $\times 1.0 \mathrm{~m}$ height $\times 3 \mathrm{~m}$ bottom width) and furrows ( $3 \mathrm{~m}$ top width $\times 1.5 \mathrm{~m}$ bottom width $\times 1.0 \mathrm{~m}$ depth). These ridges remain free of water-logging during the kharif season, with less soil salinity accumulation in dry seasons (due to higher elevation and the presence of fresh rain-water in furrows). The remaining farmland, including the furrows, is used for growing more profitable paddy and fish cultivation in the kharif season. The rain-water harvested in furrows is used for irrigation (Figure 7).

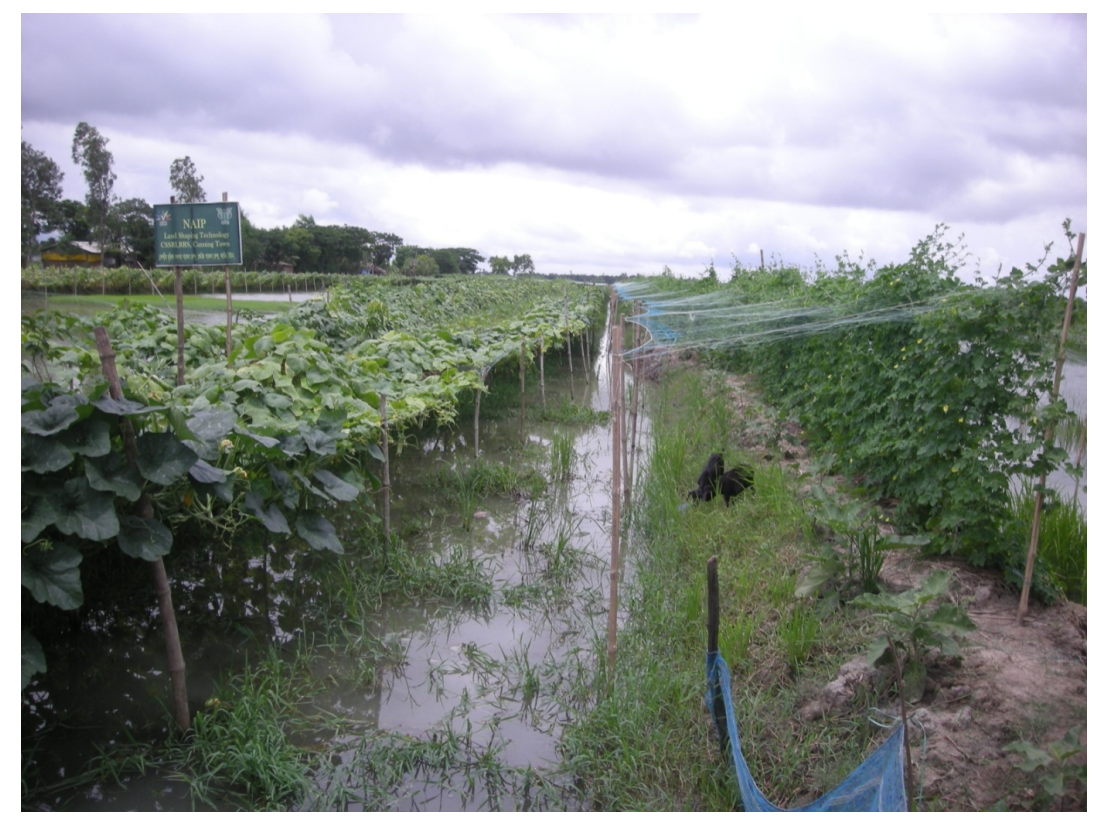

Figure 7. Deep furrow and high ridge technology at farmer's field in the Gangetic coastal region of West Bengal. 
Paddy-cum-fish: Trenches ( $3 \mathrm{~m}$ top width $\times 1.5 \mathrm{~m}$ bottom width $\times 1.5 \mathrm{~m}$ depth) are dug around the periphery of farm-land, leaving $\sim 3.5 \mathrm{~m}$ wide land to the outer boundary. The dug-out soil is used for making dikes ( $1.5 \mathrm{~m}$ top width $\times 1.5 \mathrm{~m}$ height $\times 3 \mathrm{~m}$ bottom width) to protect free flow of water from the field and harvesting more rain-water in the field and trench. A small ditch is dug out at one corner of the field as a reserve for fish when water in trenches dries out.

About 370 ha of land in disadvantaged areas in Sundarbans and the Andaman and Nicobar Islands have been converted from mono-cropped to multi-cropped. These include farm-ponds, deep furrow and high ridges, paddy-cum-fish, broad bed and furrow, the three tier system, the paired bed system and the drainage improvement network. These were under the GEF funded National Agricultural Innovation Project [144]. About 1943 water-harvesting structures were developed under various land shaping techniques, with a total water storage capacity of 1,304,600 $\mathrm{m}^{3}$ per annum. With land shaping techniques, different land situations (high land, medium land and low (original) land and rain-water harvesting structures such as farm-ponds, furrows and trenches) were created in low-lying and degraded farmers' fields. Raising of lands and creating water harvesting structures decreased drainage problems during the kharif season and provided scope for growing high value crops. These included vegetables and early sowing of rabi crops (Table 16). Salinity accumulation in soil, especially medium-level land and higher land, ridges and dikes in shaped land areas, was decreased and soil fertility status and soil biological activities increased due to land-shaping techniques. Cropping intensity increased $\leqslant 240 \%$ from a base-level value of $100 \%$. Land shaping techniques increased employment and income for households many fold. Net income per ha of farm land increased from Rs. 22,000 to Rs. 123,000 in Sundarbans and from Rs. 22,400 to Rs. 190,000 in the Andaman and Nicobar Islands. By adopting brackish water aquaculture ponds in Sundarbans, particularly near brackish rivers, farmers benefitted from this technique with a net income of $\sim$ Rs. 143,000 ha ${ }^{-1}$ of pond area. Land shaping techniques proved financially viable propositions for coastal salt affected regions [145].

\subsubsection{Integrated Soil Water Management in Rainfed Regions}

To sustainably increase crop production in rainfed areas in the semi-arid tropics, integrated approaches of managing water resources may be adopted. Approaches include in situ rain-water conservation, water-harvesting in ponds and ground-water recharge and its subsequent efficient use for enhancing productivity and reduced land degradation. Water-harvesting in ponds, recharging ground-water and supplemental irrigation supported the production of high value crops. Rainfed agriculture has traditionally been managed at the field scale. The critical importance of the systems is their capacity to bridge dry spells and, consequently, decrease risks in rainfed agriculture. A feasible strategy for realizing the potential of rainfed agriculture is harvesting a small portion of the available surplus runoff and using it for supplemental irrigation at critical crop growth stages. These practises should be integrated with soil and water conservation and balanced plant nutrition [146].

\subsection{Soil Conservation Issues in Deserts}

Sand dune stabilization prevents sand drift and can also be turned in to an economic activity by providing 15-20 $\mathrm{t} /$ ha of wood five years after plantation [55]. The C:B ratio of sand dune stabilization has been estimated to vary from 1.83 to 3.58 , depending upon locality [147]. The impact of surface cover factor on wind erosion control technology was demonstrated from a field experiment at two grazing situations in the Jaisalmer Region of the Thar Desert [63]. The aeolian mass transport rate was almost three times higher at the overgrazed site than at the controlled grazing site during hot summer months. 
Table 16. Impact of different land shaping techniques in the Sundarbans region (Source: Burman et al. [145]).

\begin{tabular}{|c|c|c|c|c|c|c|c|c|c|}
\hline \multirow{2}{*}{ Land Shaping Models } & \multirow{2}{*}{$\begin{array}{l}\text { Land Situation } \\
\text { Created }\end{array}$} & \multicolumn{2}{|c|}{ Crops } & \multirow{2}{*}{$\begin{array}{l}\text { Water Harvesting } \\
\text { Capacity }\left(\mathrm{m}^{3}\right) / \mathrm{ha} \\
\quad \text { (in \% area) }\end{array}$} & \multirow{2}{*}{$\begin{array}{c}\text { Rice } \\
\text { Equivalent } \\
\text { Yield (REY) } \\
\text { (kg/ha) }\end{array}$} & \multicolumn{3}{|c|}{$\begin{array}{l}\begin{array}{l}\text { Operational Cost and Returns (Kharif }+ \text { Rabi) } \\
\text { (Rs./ha) }\end{array} \\
\end{array}$} & \multirow{2}{*}{$\begin{array}{l}\text { Benefit-Cost } \\
\text { Ratio (Rank) }\end{array}$} \\
\hline & & Kharif Season & Rabi/Summer Season & & & Total Cost & Total Return & Net Return & \\
\hline \multirow{4}{*}{ Farm Pond (FP) } & (a) Pond $(20 \%)$ & Fish & Fish & & 3313 & 15,172 & 59,162 & 43,990 & \\
\hline & $\begin{array}{l}\text { (b) High land and } \\
\text { dikes }(20 \%)\end{array}$ & $\begin{array}{l}\text { Vegetables, fruit } \\
\text { crops }\end{array}$ & Vegetables, fruit crops & & 5177 & 17,700 & 48,206 & 30,506 & \\
\hline & (c) Medium land (20\%) & HYV Rice & $\begin{array}{l}\text { Vegetables, low water } \\
\text { requiring field crops }\end{array}$ & & 2976 & 14,792 & 39,175 & 24,383 & \\
\hline & $\begin{array}{l}\text { (d) Original } \\
\text { lowland (40\%) }\end{array}$ & Paddy + fish & $\begin{array}{l}\text { Low water requiring } \\
\text { field crops/vegetables, } \\
\text { short duration rice }\end{array}$ & & 3546 & 18,459 & 48,769 & 30,311 & \\
\hline Total & & & & $5000(20 \%)$ & 15,012 & 66,123 & 195,313 & 85,199 & $2.95(1)$ \\
\hline \multirow{3}{*}{$\begin{array}{l}\text { Deep furrow and high } \\
\text { ridge (DF) }\end{array}$} & (a) Furrows (25\%) & paddy + Fish & Fish & & 5316 & 32,778 & 92,824 & 60,046 & \\
\hline & (b) Ridges (25\%) & $\begin{array}{l}\text { Vegetables and } \\
\text { fruit } \\
\text { crops/multi-purpose } \\
\text { tree species }\end{array}$ & $\begin{array}{l}\text { Vegetables and fruit } \\
\text { crops } / \text { multi-purpose } \\
\text { tree species (MPTs) }\end{array}$ & & 2953 & 18,730 & 43,151 & 24,421 & \\
\hline & $\begin{array}{l}\text { (c) Original } \\
\text { lowland (50\%) }\end{array}$ & $\begin{array}{l}\text { Rice under paddy } \\
+ \text { fish }\end{array}$ & $\begin{array}{l}\text { Low water requiring } \\
\text { field crops/vegetables }\end{array}$ & & 4219 & 20,916 & 31,504 & 10,588 & \\
\hline Total & & & & $1875(25 \%)$ & 12,488 & 72,424 & 167,479 & 95,055 & $2.31(2)$ \\
\hline
\end{tabular}


Table 16. Cont.

\begin{tabular}{|c|c|c|c|c|c|c|c|c|c|}
\hline \multirow{2}{*}{ Land Shaping Models } & \multirow{2}{*}{$\begin{array}{l}\text { Land Situation } \\
\text { Created }\end{array}$} & \multicolumn{2}{|c|}{ Crops } & \multirow{2}{*}{$\begin{array}{l}\text { Water Harvesting } \\
\text { Capacity }\left(\mathrm{m}^{3}\right) / \mathrm{ha} \\
\text { (in } \% \text { area) }\end{array}$} & \multirow{2}{*}{$\begin{array}{c}\text { Rice } \\
\text { Equivalent } \\
\text { Yield (REY) } \\
\text { (kg/ha) }\end{array}$} & \multicolumn{3}{|c|}{$\begin{array}{l}\text { Operational Cost and Returns (Kharif }+ \text { Rabi) } \\
\text { (Rs./ha) }\end{array}$} & \multirow{2}{*}{$\begin{array}{l}\text { Benefit-Cost } \\
\text { Ratio (Rank }\end{array}$} \\
\hline & & Kharif Season & Rabi/Summer Season & & & Total Cost & Total Return & Net Return & \\
\hline \multirow{3}{*}{ Paddy-cum-fish (PCF) } & (a) Trenches $(11 \%)$ & $\begin{array}{l}\text { Fish under paddy } \\
+ \text { Fish }\end{array}$ & Fallow & & 1919 & 32,254 & 78,985 & 46,731 & \\
\hline & (b) Dikes (12\%) & $\begin{array}{l}\text { Vegetables and } \\
\text { fruit crops/MPTs }\end{array}$ & $\begin{array}{l}\text { Vegetables and fruit } \\
\text { crops/MPTs }\end{array}$ & & 1873 & 9707 & 29,559 & 19,852 & \\
\hline & $\begin{array}{l}\text { (c) Original low } \\
\text { land }(77 \%)\end{array}$ & Paddy + fish & $\begin{array}{l}\text { Low water requiring } \\
\text { field crops/vegetables }\end{array}$ & & 8321 & 26,133 & 36,307 & 10,174 & \\
\hline Total & & & & $1400(12 \%)$ & 12,113 & 68,094 & 144,851 & 76,757 & $2.13(3)$ \\
\hline \multirow{3}{*}{$\begin{array}{l}\text { Paddy-cum-fish+brackish } \\
\text { water fish (PCF + BWF) }\end{array}$} & (a) Trenches $(11 \%)$ & paddy + Fish & Brackish water Fish & & 1963 & 123,817 & 261,054 & 137,237 & \\
\hline & (b) Dikes (12\%) & Vegetables & - & & 1821 & 10,148 & 21,209 & 11,061 & \\
\hline & $\begin{array}{l}\text { (c) Original low } \\
\text { land }(77 \%)\end{array}$ & Paddy + fish & Brackish water Fish & & 7937 & 82,327 & 154,993 & 220,964 & \\
\hline Total & & & & $1400(12 \%)$ & 11,721 & 216,291 & 437,255 & 220,964 & $2.02(4)$ \\
\hline \multirow{3}{*}{$\begin{array}{l}\text { Shallow furrow and } \\
\text { medium ridge (SF) }\end{array}$} & (a) Furrows $(20 \%)$ & paddy + Fish & Rice & & 1904 & 32,669 & 89,237 & 56,568 & \\
\hline & (b) Ridges (20\%) & $\begin{array}{l}\text { Vegetables and } \\
\text { fruit crops/MPTs }\end{array}$ & $\begin{array}{l}\text { Vegetables and fruit } \\
\text { crops/MPTs }\end{array}$ & & 2703 & 16,928 & 20,584 & 3656 & \\
\hline & $\begin{array}{l}\text { (c) Original low } \\
\text { land }(60 \%)\end{array}$ & Paddy + fish & $\begin{array}{l}\text { Low water requiring } \\
\text { field crops/vegetables }\end{array}$ & & 6509 & 24,667 & 29,770 & 5103 & \\
\hline Total & & & & $1125(20 \%)$ & 11,116 & 74,265 & 139,591 & 65,327 & $1.88(5)$ \\
\hline Control (farmers' practise) & & & & & 3111.0 & 20,487 & 25,436 & 4949 & $1.24(6)$ \\
\hline
\end{tabular}


Shelterbelt technology is widely adopted in the Thar Desert, where water resources are available either through the tube-well command area (e.g., Lathi series in Jaisalmer) or the Indira Gandhi Nahar Project (IGNP) command area. About $20 \%$ of the total 20,000 ha tube-well irrigated area in villages of the Lathi series has been put under shelterbelts, whereas only $5 \%$ of 9.25 lac ha area of IGNP-Phase II is covered with such plantations [71]. Planting of tree shelterbelts along farm boundaries has been proved beneficial in protecting crops from extreme weather and improving field microclimates. Shelterbelt technology is also adopted by IGNP canal command area authorities and road maintenance engineering staff. Sand deposition in IGNP canals has been considerably decreased by planting tree shelterbelts along canals. The corresponding savings on removing deposited sand is estimated to be Rs 6156-12,276 per km. Problem of road blockage by blowing sand has also been considerably avoided by planting trees along roadsides by the General Reserve Engineering Force (GREF) in Jaisalmer.

The impacts of micro-shelterbelts have been studied at ICAR-Central Arid Zone Research Institute, Jodhpur [148]. Three rows of pearl millet could increase the summer yield of cowpea and okra by $21 \%$ and $44 \%$, respectively, compared with unsheltered crops. Sheltered field provided additional income from pearl millet fodder. Soni et al. [149] have reported that in Bikaner, strip cropping of Cenchrus cilliaris with clusterbean in a 5:15 metre row:width ratio decreased soil loss from 67.5 and $33.5 \mathrm{t} \cdot \mathrm{ha}^{-1}$ in sole cropping in 2006 and 2007 to only $7.5 \mathrm{t} \cdot \mathrm{ha}^{-1}$. Net loss of SOC decreased 3-6 fold under strip cropping compared to sole cropping and NPK loss decreased five to seven fold.

\section{Conclusions}

Soil erosion is the major land degradation process in India. In the changing climate scenario, such problems (wind and water erosion) are expected to increase due to forecasting of high intensity storms and denudation of forest cover. Hence, there is a need to mainstream treatment of such problem areas into watershed programmes. Considering the causative factors of soil erosion, different control measures have been formulated, which mainly aim either to decrease the erosive energy of wind and water or to decrease soil erodibility by altering surface soil characteristics, surface cover or roughness. Among different measures, watershed development is the most applicable holistic method to control soil erosion, which may be achieved through maintaining permanent grass cover on rangelands. Watershed programmes are contributing to increasing incomes (more so in the poor income regions compared with higher income regions). Benefits with the available technologies were more in regions with 700-1000 mm annual rainfall. Information may be generated for the development of suitable technological interventions for low ( $<700 \mathrm{~mm} /$ year) and high $(>1000 \mathrm{~mm} /$ year) rainfall regions. Watershed programmes should be a vehicle of development to alleviate poverty.

The benefits of watershed projects increased with public participation. In the absence of user involvement, watershed programmes would be unsustainable. In the watershed programmes, so far the focus has been on resource conservation and productivity enhancement on agricultural lands. More focus is needed on: involvement of elected institutions, good local leadership, pre-disposition of the community for collective action and establishment of effective linkages of watershed institutions with other institutions, such as the input delivery systems, the credit sectors and technology transfer systems.

Inappropriate institutional arrangement is the major obstacle in watershed development programmes. The aim should be to conserve soil and water on all lands. For this, the productive capacity of all soils and landscapes with their proper use should be matched, along with appropriate policies and technologies. The socio-economic and physical factors, which drive soil erosion must be addressed in tandem. People's mind-sets should be to improve the ability to adapt soil conservation practises to combat degradation and the impacts of future climate change. For this, education at all levels is necessary. Policies need to acknowledge the interconnectivity of watershed systems in the landscape, by integrating water management policies and related mechanisms. Increased attention to forage crop and grazing management will lead to revitalized rural communities. Increased attention to integrated nutrient management and conservation agriculture, coupled with tree shelterbelts and animal rearing, will lead to environmental protection and conservation of key natural resources [1]. 
Author Contributions: Ranjan Bhattacharyya and Michael Augustine Fullen conceived and designed the whole review work based on invitation from the Guest Editor. Ranjan Bhattacharyya, Birendra Nath Ghosh, Pradeep Dogra, Prasanta Kumar Mishra, Priyabrata Santra, Suresh Kumar, Uttam Kumar Mandal, Dibyendu Sarkar, Krishnendu Das, Dibyendu Mukhopadhyay, Kokkuvayil Sankaranarayanan Anil, Manickam Lalitha, Madan Pal, Rajbir Yadav, Ved Prakash Chaudhary and Brajendra Parmar wrote the paper. Ranjan Bhattacharyya and Michael Augustine Fullen edited the entire manuscript.

Conflicts of Interest: The authors declare no conflict of interest.

\section{Glossary of Indian terms:}

Khar means brackish

Pokhali soil means acid sulphate soils ( $\mathrm{pH}$ 3.5)

Ber is a tree (Ziziphus mauritiana)

kakh is a type of pit

Rabi season means winter season

khali means empty

Kharif season means rainy season

1 Lakh/Lac Rupees $=100,000$ Rupees

\section{References}

1. Bhattacharyya, R.; Ghosh, B.N.; Mishra, P.K.; Mandal, B.; Rao, C.S.; Sarkar, D.; Das, K.; Anil, K.S.; Lalitha, M.; Hati, K.M.; et al. Soil degradation in India: Challenges and potential. Sustainability 2015, 7, 3528-3570. [CrossRef]

2. NAAS. Management of Crop Residues in the Context of Conservation Agriculture; Policy Paper No. 58; National Academy of Agricultural Sciences: New Delhi, India, 2012; p. 12.

3. NRSA. Waste Land Atlas of India; Government of India, Balanagar: Hyderabad, India, 1985.

4. Sehgal, J.; Abrol, I.P. Soil Degradation in India: Status and Impact; Oxford and IBH: New Delhi, India, $1994 ;$ p. 80.

5. Sharda, V.N.; Mandal, D. Priority Classes for Erosion Risk Areas in Different States and Regions of India; Bulletin No. T-58/D-37; Central Soil and Water Conservation Research and Training Institute: Dehradun, India, 2011; p. 172.

6. Bhattacharyya, R.; Kundu, S.; Pandey, S.; Singh, K.P.; Gupta, H.S. Tillage and irrigation effects on crop yields and soil properties under rice-wheat system of the Indian Himalayas. Agric. Water Manag. 2008, 95, 993-1002. [CrossRef]

7. Singh, G.; Babu, R.; Narain, P.; Bhushan, L.S.; Abrol, I.P. Soil erosion rates in India. J. Soil Water Conserv. 1992, 47, 97-99.

8. Ghosh, B.N.; Dogra, P.; Bhattacharyya, R.; Sharma, N.K.; Dadhwal, K.S. Effects of grass vegetative strips on soil conservation and crop yield under rainfed conditions in the Indian sub-Himalayas. Soil Use Manag. 2012, 28, 635-646. [CrossRef]

9. Timsina, J.; Connor, D.J. Productivity and management of rice-wheat cropping systems: Issues and challenges. Field Crop Res. 2001, 69, 93-132. [CrossRef]

10. Singh, R.B. Environmental consequences of agricultural development: A case study from the Green Revolution state of Haryana, India. Agric. Ecosyst. Environ. 2000, 82, 97-103. [CrossRef]

11. Hira, G.S. Water management in northern states and the food security of India. J. Crop Improv. 2009, 23, 136-157. [CrossRef]

12. Chauhan, B.S.; Mahajan, G.; Sardana, V.; Timsina, J.; Jat, M.L. Productivity and sustainability of the rice-wheat cropping system in the Indo-Gangetic Plains of the Indian subcontinent: Problems, Opportunities, and Strategies. Adv. Agron. 2012, 111, 315-369.

13. Kumar, R.; Gopal, R.; Jat, M.L.; Gupta, R.K. Conservation Agriculture Based Strategies for Sustainable Weed Management in Maize (Zea mays); Training Manual, Maize for Freshers; Directorate of Maize Research: New Delhi, India, 2010.

14. Rodell, M.; Velicigna, I.; Famiglietti, J.S. Satellite-based estimates of groundwater depletion in India. Nature 2009, 460, 999-1002. [CrossRef] [PubMed]

15. Tandon, H.L.S.; Sekhon, G.S. Potassium Research and Agricultural Production in India; Fertilizer Development and Consultation Organization: New Delhi, India, 1988. 
16. Singh, B.; Singh, Y.; Imas, P.; Xie, J. Potassium nutrition of rice-wheat cropping system. Adv. Agron. 2004, 81, 203-259.

17. Mandal, B.; Majumder, B.; Bandopadhyay, P.K.; Hazra, G.C.; Gangopadhyay, A.; Samantaroy, R.N.; Misra, A.K.; Chowdhuri, J.; Saha, M.N.; Kundu, S. The potential of cropping systems and soil amendments for carbon sequestration in soils under long-term experiments in subtropical India. Glob. Chang. Biol. 2007, 13, 357-369. [CrossRef]

18. Saha, M.N.; Saha, A.R.; Mandal, B.C.; Roy, P.K. Effect of long-term jute-R-W cropping system on crop yield and soil fertility. In Long-term Soil Fertility Experiments in R-W Cropping Systems; Abrol, I.P., Bronson, K.F., Duxbury, J.M., Gupta, R.K., Eds.; R-W Consortium Paper Series 6; R-W Consortium for the IGPs: New Dehli, India, 2000; pp. 94-104.

19. Lal, R. Soil carbon sequestration in India. Clim. Chang. 2004, 65, 277-296. [CrossRef]

20. Bhattacharyya, R.; Tuti, M.D.; Kundu, S.; Bisht, J.K.; Bhatt, J.C. Conservation tillage impacts on soil aggregation and carbon pools in a sandy clay loam soil of the Indian Himalayas. Soil Sci. Soc. Am. J. 2012, 76, 617-627. [CrossRef]

21. Sarkar, A.; Yadav, R.L.; Gangwar, B.; Bhatia, P.C. Crop Residues in India; Technical Bulletin; Directorate of Cropping System Research: Modipuram, India, 1999.

22. Singh, B.; Shan, Y.H.; Johnson-Beebout, S.E.; Singh, Y.; Buresh, R.J. Crop residue management for lowland rice-based cropping systems in Asia. Adv. Agron. 2008, 98, 117-199.

23. Mandal, K.G.; Misra, A.K.; Hati, K.M.; Bandyopadhyay, K.K.; Ghosh, P.K.; Mohanty, M. Rice residue-management options and effects on soil properties and crop productivity. Food Agric. Environ. 2004, 2, 224-231.

24. ICAR. Enhancing the Biodegradation of Rice Residue in Rice-Based Cropping Systems to Sustain Soil Health and Productivity; Technical Project Representative; Indian Council of Agricultural Research: New Delhi, India, 1999.

25. Benbi, D.K.; Manchanda, J.S.; Gossal, S.K.; Walia, S.S.; Toor, A.S.; Minhas, P.S. Soil Health Issues for Sustaining Agriculture in Punjab; Research Bulletin 4/2011; Directorate of Research, Punjab Agricultural University: Ludhiana, India, 2011.

26. Singh, B.; Singh, Y. Management of crop residues in rice-wheat cropping system in the Indo-Gangetic Plains. In Nutrient Management for Sustainable Rice-Wheat Cropping System; Singh, Y., Singh, B., Nayyar, V.K., Singh, J., Eds.; National Agricultural Technology Project, Indian Council of Agricultural Research: New Delhi, India; Punjab Agricultural University: Ludhiana, India, 2003; pp. 286-301.

27. Sharma, P.K. Effect of Crop Residue Management Practices and Green Manuring on Nutrient Dynamics and Soil Productivity in Rice-Wheat Cropping System. Ph.D. Thesis, G.B. Pant University of Agriculture and Technology, Pantnagar, India, 1998.

28. Lefroy, R.D.B.; Chaitep, W.; Blair, G.J. Release of sulphur from rice residue under flooded and non flooded soil conditions. Aust. J. Agric. Res. 1994, 45, 657-667. [CrossRef]

29. Lal, R. Soil Erosion in the Tropics: Principles and Management; McGraw-Hill: New York, USA, 1990.

30. Kar, A.; Moharana, P.C.; Raina, P.; Kumar, M.; Soni, M.L.; Santra, P.; Ajai; Arya, A.S.; Dhinwa, P.S. Desertificatiion and its control measures. In Trends in Arid Zone Research in India; Kar, A., Garg, B.K., Singh, M.P., Kathju, S., Eds.; Central Arid Zone Research Institute: Jodhpur, India, 2009; pp. 1-47.

31. Dey, B.N. Reclamation of Sand Dunes and Other Shifting Sand Dunes. Available online: http://www. indianforester.co.in/index.php/indianforester/article/view/24255 (accessed on 16 June 2016).

32. Kaul, R.N. Shelterbelt to stop creep of the desert. Indian For. 1959, 85, 191-195.

33. Bhimaya, C.P.; Kaul, R.N.; Ganguli, B.N. Sand dune rehabilitation in Western Rajasthan. In Proceedings of the Fifth World Forestry Congress, Seattle, WA, USA, 29 August-10 September 1960; pp. 358-363.

34. Bhimaya, C.P.; Choudhary, M.D. Plantation of windbreaks in the central mechanized farm, Suratgarh. Indian For. 1961, 87, 354-367.

35. Schwab, G.O.; Fangmeier, D.D.; Elliot, W.J.; Frevert, R.K. Soil and Water Conservation Engineering, 4th ed.; John Wiley \& Sons, Inc.: New York, USA, 1993; pp. 131-138.

36. Santra, P.; Mertia, R.S. Air pollution through particulate matter and its impact on human health. Available online: http:/ /nopr.niscair.res.in/handle/123456789/7415 (accessed on 16 June 2016). 
37. Yadav, J.S.P. Irrigation induced soil salinity and sodicity. In Proceedings of the World Food Day Symposium on Environmental Problems Affecting Agriculture in the Asia and Pacific Region held at FAO, Bangkok, Thailand, 11 October 1989; pp. 47-62.

38. Pathak, P.; Mishra, P.K.; Rao, K.V.; Wani, S.P.; Sudi, R. Best options on soil and water conservation. In Best Bet Options for Integrated Watershed Management, Proceedings of the Comprehensive Assessment of Watershed Programs in India, Andhra Pradesh, India, 23-27 July 2009; Wani, S.P., Venkateshwarlu, B., Sahrawat, K.L., Rao, K.V., Ramakrishna, Y.S., Eds.; ICRISAT: Pantancheru, India, 2009; pp. 75-94.

39. Sharda, V.N.; Dogra, P.; Prakash, C. Potential Technologies for Resource Conservation and Productivity Enhancement; Technical Bulletin No.T-57/D-36. ICAR-IISWC (Formerly known as CSWCRT\&I); Allied Publisher: Dehradun, India, 2009; pp. 1-150.

40. Bansal, R.C.; Mathur, H.N. Landslides-The nightmares of hill roads. Soil Conserv. Dig. 1976, 4, 36-37.

41. CSWCR\&TI. Vision, 2030; 2030 Vision Document of the Central Soil and Water Conservation Research and Training Institute; Allied Publisher: Dehradun, India, 2011; pp. 1-46.

42. Rana, N.; Singh, S.; Sundriayal, Y.P.; Juyal, N. Recent and past floods in the Alaknanda Valley: Causes and consequences. Curr. Sci. 2013, 105, 1209-1212.

43. Joshi, P.K.; Jha, A.K.; Wani, S.P.; Joshi, L.; Shiyani, R.L. Meta-Analysis to Assess Impact of Watershed Program and People's Participation; Comprehensive Assessment Research Report; Comprehensive Assessment Secretariat: Colombo, Sri Lanka, 2005.

44. Ahluwalia, M.S. Reducing Poverty and Hunger in India: The Role of Agriculture. Available online: http: //planningcommission.nic.in/aboutus/speech/spemsa/msa046.pdf (accessed on 15 June 2016).

45. Wani, S.P.; Ramakrishna, Y.S.; Sreedevi, T.K.; Long, T.D.; Thawilkal, W.; Shiferaw, B.; Pathak, P.; Kesava Rao, A.V.R. Experience and lessons from Asia in integrated management of watershed for agricultural diversification and sustainable livelihoods in Eastern and Central Africa: Lessons and experiences from Semi-Arid South Asia. In Proceedings of the International Workshop on Watershed Management, Nairobi, Kenya, 6-7 December 2004; pp. 17-36.

46. Joshi, P.K.; Jha, A.K.; Wani Suhas, P.; Sreedevi, T.K.; Shaheen, F.A. Impact of Watershed Program and Conditions for Success: A Meta-Analysis Approach; Global Theme on Agroecosystems Report No. 46; International Crops Research Institute for the Semi-Arid Tropics: Patancheru, India, 2008; p. 24.

47. Wani, S.P.; Sreedevi, T.K.; Rockstrom, J.; Wangkahart, T.; Ramakrishna, Y.S.; Yin, D.; Kesava Rao, A.V.R.; Zhong, L. Improved livelihoods and food security through unlocking the potential of rain-fed agriculture. In Food and Water Security; Aswathanarayana, U., Ed.; Taylor \& Francis: Abingdon/Oxford, UK, 2007; pp. 89-106.

48. Wani, S.P.; Singh, H.P.; Sreedevi, T.K.; Pathak, P.; Rego, T.J.; Shiferaw, B.; Iyer, S.R. Farmer-participatory integrated watershed management: Adarsha Watershed, Kothapally India: An innovative and up-scaleble approach. In Research towards Integrated Natural Resources Management: Examples of Research Problems, Approaches and Partnerships in Action in the CGIAR; Harwood, R.R., Kassam, A.H., Eds.; Interim Science Council and Centre Directors Committee on Integrated Natural Resources Management, Consultative Group on International Agricultural Research: Washington, DC, USA; Food and Agriculture Organization: Rome, Italy, 2003; pp. 123-147.

49. Harsh, L.N.; Mertia, R.S.; Tewari, J.C. Shelterbelt plantation for ameliorating the microclimate and for higher crop production. In Prospects of Indira Gandhi Canal Project; Abrol, I.P., Venkateswarlu, J., Eds.; Publications and Information Division, Indian Council of Agricultural Research: New Delhi, India, 1991; pp. 74-81.

50. Chepil, W.S.; Woodruff, N.P. The physics of wind erosion and its control. Advan. Agron. 1963, 15, $211-302$.

51. Tibke, G. Basic principles of wind erosion control. Agric. Ecosyst. Environ. 1988, 22-23, 103-122. [CrossRef]

52. Li, B.; Sherman, D.J. Aerodynamics and morphodynamics of sand fences: A review. Aeolian Res. 2015, 17, 33-48. [CrossRef]

53. Muthana, K.D. A review of sand dune stabilization and afforestation. In Proceedings of the Workshop on the Problems of the Deserts in India, Jaipur, India, 16-18 September 1975; Geological Survey of India: Kolkata, India, 1982; pp. 363-368.

54. Gupta, J.P.; Rao, G.S.N.; Ramakrishna, Y.S.; Rao, B.V.R. Role of shelterbelts in arid zones. Indian Farming 1984, $29-30$. 
55. Kaul, O.N. Forest production on sand dunes. In FAO Conservation Guide, Sand Dune Stabilisation, Shelterbelts and Afforestation in Dry Zones; Food and Agriculture Organization of the United Nations: Rome, Italy, 1985; pp. 87-95.

56. Mann, H.S. Wind erosion and its control. In FAO Conservation Guide, Sand Dune Stabilisation, Shelterbelts and Afforestation in Dry Zones; Food and Agriculture Organization of the United Nations: Rome, Italy, 1985; pp. 125-132.

57. Mertia, R.S. Shelterbelt research in arid zones. J. Trop. For. 1992, 8, 196-200.

58. Kar, A.; Joshi, D.C. Sand movement and control of aeolian hazard. In Land Degradation and Desertification in Asia and the Pacific Region; Sen, A.K., Kar, A., Eds.; Scientific Publishers: Jodhpur, India, 1995; pp. $19-40$.

59. Venkateswarlu, J.; Kar, A. Wind erosion and its control in arid north-west India. Ann. Arid Zone 1996, 35, 85-99.

60. Narain, P.; Kar, A. Desertification and Its Control in India. In Human and Nature-Working Together for Sustainable Development of Drylands; El-Beltagy, A., Saxena, M.C., Wang, T., Eds.; International Centre for Agricultural Research in Dry Areas (ICARDA): Aleppo, Syria, 2007; pp. 84-94.

61. Woodruff, N.P.; Lyles, L.; Siddoway, F.H.; Fryrear, D.W. How to Control Wind Erosion; USDA ARS Agriculture Information Bulletin No. 354; United States Department of Agriculture (USDA): Washington, DC, USA, 1972.

62. Fryrear, D.W.; Bilbro, J.D. Wind erosion control with residues and related practices. In Managing Agricultural Residues; Unger, P.W., Ed.; Lewis: Boca Raton, FL, USA, 1994; pp. 7-17.

63. Mertia, R.S.; Santra, P.; Kandpal, B.K.; Prasad, R. Mass-Height profile and total mass transport of wind eroded aeolian sediments from rangelands of Indian Thar Desert. Aeolian Res. 2010, 2, 135-142. [CrossRef]

64. Skidmore, E.L.; Hagen, L.J. Reducing wind erosion with barriers. Trans. ASAE 1977, 20, 911-915. [CrossRef]

65. Kort, J. Benefits of windbreaks to field and forage crops. Agric. Ecosyst. Environ. 1988, 22-23, 165-190. [CrossRef]

66. Mohammed, A.E.; Stigter, C.J.; Adam, H.S. On shelterbelt design for combating sand invasion. Agric. Ecosyst. Environ. 1996, 57, 81-90. [CrossRef]

67. Cornelis, W.M.; Gabriels, D. Optimal windbreak design for wind-erosion control. J. Arid Environ. 2005, 61, 315-332. [CrossRef]

68. Raheja, P.C. Shelterbelts in arid climates and special techniques for tree planting. Ann. Arid Zone 1963, 122, $1-13$.

69. Ganguly, J.K.; Kaul, R.N. Wind erosion control. ICAR, New Delhi. Available online: http://14.139.58.78/cgibin/koha/opac-detail.pl?biblionumber=9793 (accessed on 16 June 2016).

70. Vora, A.B.; Parappillil, A.J.; Sharma, K.S. Effect of wind break and shelterbelts on wheat and mustard as well as on wind velocity. Indian For. 1982, 108, 215-220.

71. Mertia, R.S.; Prasad, R.; Gajja, B.L.; Samra, J.S.; Narain, P. Impact of shelterbelt in arid region of western Rajasthan; CAZRI Research Bulletin: Jodhpur, India, 2006.

72. Food and Agriculture Organization (FAO). Climate-Smart Agriculture. Policies, Practices and Financing for Food Security, Adaptation and Mitigation; FAO: Rome, Italy, 2010; p. 41.

73. Hobbs, P.R.; Sayre, K.; Gupta, R. The role of conservation agriculture in sustainable agriculture. Phil. Trans. R. Soc. B 2008, 363, 543-555. [CrossRef] [PubMed]

74. Rai, H.K.; Sharma, A.; Soni, U.A.; Khan, S.A.; Kumari, K.; Kalra, N. Simulating the impact of climate change on growth and yield of wheat. J. Agrometeorol. 2004, 6, 1-8.

75. Hobbs, P.R.; Gupta, R.K. Resource-conserving technologies for wheat in the rice-wheat system. In Improving the Productivity and Sustainability of Rice-Wheat Systems: Issues and Impacts; Ladha, J.K., Hill, J.E., Duxbury, J.M., Gupta, R.K., Buresh, R.J., Eds.; ASA Special Publication 65, SSSA Inc.: Madison, WI, USA, 2003; pp. $149-171$.

76. Mehla, R.S.; Verma, J.K.; Gupta, R.K.; Hobbs, P.R. Stagnation in the Productivity of Wheat in the Indo-Gangetic Plains: Zero-till-Seed cum-Fertilizer Drill as an Integrated Solution; Rice-Wheat Systems of the Indo-Gangetic Plains; RWC Paper Series No.8; International Maize and Wheat Improvement Centre (CIMMYT): New Delhi, India, 2000; p. 9.

77. Jat, M.L.; Gathala, M.K.; Saharawat, Y.S.; Terawal, J.P.; Gupta, R.; Singh, Y. Double no-till and permanent raised beds in maize-wheat rotation of north-western Indo-Gangetic plains of India: Effects on crop yields, water productivity, profitability and soil physical properties. Field Crops Res. 2013, 149, 291-299. [CrossRef]

78. Bhattacharyya, R.; Abrol, I.P. Conservation agriculture. In Soil Science-An Introduction; Indian Society of Soil Science: New Delhi, India, 2015. 
79. Jat, M.L.; Gathala, M.K.; Ladha, J.K.; Saharawat, Y.S.; Jat, A.S.; Vipin Kumar, A.S.; Sharma, S.K.; Kumar, V.; Gupta, R.K. Evaluation of precision land leveling and double zero-till systems in the rice-wheat rotation: Water use, productivity, profitability and soil physical properties. Soil Tillage Res. 2009, 105, 112-121.

80. Jat, M.L.R.G.; Ramasundaram, P.; Gathala, M.K.; Sidhu, H.S.; Singh, S.; Singh, R.G.; Saharawat, Y.S.; Kumar, V.; Chandna, P.; Ladha, J.K. Laser-assisted precision land leveling: A potential technology for resource conservation in irrigated intensive production systems of the Indo-Gangetic Plains. In Integrated Crop and Resource Management in the Rice-Wheat System of South Asia; Ladha, J.K., Yadvinder, S., Erenstein, O., Hardy, B., Eds.; International Rice Research Institute: Los Baños, Philippines, 2009; pp. 223-238.

81. Sidhu, H.S. Cereal Systems Initiative for South Asia (CSISA); Annual Report; CSISA Punjab Hub: Ludhiana, India, 2010.

82. Saharawat, Y.S.; Singh, B.; Malik, R.K.; Ladha, J.K.; Gathala, M.; Jat, M.L.; Kumar, V. Evaluation of alternative tillage and crop establishment methods in a rice-wheat rotation in North Western IGP. Field Crop Res. 2010, 116, 260-267. [CrossRef]

83. Gathala, M.K.; Ladha, J.K.; Kumar, V.; Saharawat, Y.S.; Kumar, V.; Sharma, P.K.; Sharma, S.; Pathak, H. Tillage and crop establishment affects sustainability of South Asian rice-wheat system. Agron. J. 2011, 103, 961-971. [CrossRef]

84. Parihar, C.M.; Jat, S.L.; Singh, A.K.; Jat, M.L. Energy scenario and water productivity of maize based cropping system under conservation agriculture practices in South Asia. In Proceedings of the 5th World Congress on Conservation Agriculture Incorporating 3rd Farming Systems Design Conference, Brisbane, Australia, 25-29 September 2011; pp. 144-145.

85. Gathala, M.K.; Saharawat, Y.S.; Ladha, J.K. Integrated Crop and Resource Management in Rice-Wheat Systems; Annual Report; CSISA Research Platform; CSSRI: Karnal, India, 2010.

86. Jat, M.L.; Singh, R.G.; Saharawat, Y.S.; Gathala, M.K.; Kumar, V.; Sidhu, H.S.; Gupta, R. Innovations through conservation agriculture: Progress and prospects of participatory approach in the Indo-Gangetic plains. In Proceedings of the 4th World Congress on Conservation Agriculture, New Delhi, India, 4-7 February 2009; pp. 60-64.

87. Das, T.K.; Bhattacharyya, R.; Sudhishri, S.; Sharma, A.R.; Saharawat, Y.S.; Bandyopadhyay, K.K.; Sepat, S.; Bana, R.S.; Aggarwal, P.; Sharma, R.K.; et al. Conservation agriculture in an irrigated cotton-wheat system of the western Indo-Gangetic Plains: Crop \& water productivity and economic profitability. Field Crops Res. 2014, 158, 24-33.

88. Jat, M.L.; Chandana, P.; Sharma, S.K.; Gill, M.A.; Gupta, R.K. Laser Land Leveling: A Precursor Technology for Resource Conservation; Rice-Wheat Consortium Technical Bulletin Series 7; Rice-Wheat Consortium: New Delhi, India, 2006; p. 36.

89. Gill, M.S.; Kumar, A.; Kumar, P. Growth and yield of rice cultivars under various methods and time of sowing. Indian J. Agron. 2006, 51, 123-127.

90. Gupta, R.; Jat, M.L. Cereal Systems Initiative for South Asia (CSISA); Delivery and Adaptive Research, Annual Report; NASC Complex; International Maize and Wheat Improvement Centre (CIMMYT): New Delhi, India, 2010.

91. Jat, M.L.; Sharma, S.K.; Rai, H.K.; Srivastava, A.; Gupta, R.K. Effect of tillage on performance of winter maize in northern India. In Proceedings of Maize Association of Australia, 6th Triennial Conference Darlington Point, Griffith, NSW, Australia, 21-23 February 2006; Humphreys, E., O’Keeffe, K., Hutchins, N., Gill, R., Eds.; Maize Association of Australia: Griffith, Australia, 2006; pp. 293-299.

92. Jat, M.L.; Gupta, R.; Saharawat, Y.S.; Khosla, R. Layering precision land leveling and furrow irrigated raised bed planting: Productivity and input use efficiency of irrigated bread wheat in the Indo-Gangetic Plains. Am. J. Plant Sci. 2011, 2, 1-11. [CrossRef]

93. Chandra, R.; Sikka, A.; Singh, S.; Gupta, R.; Upadhyaya, A.K.; Sakthivadivel, R. Impact of Resource Conserving Technologies on Water Use and Water Productivity in Pabnawa Minor of Bhakra Canal System; RWC Technical Bulletin No. 10; Rice-Wheat Consortium: New Delhi, India, 2007.

94. Rice-Wheat Consortium. RWC-CIMMYT. Addressing Resource Conservation Issues in Rice-Wheat Systems of South Asia: A Resource Book; Rice-Wheat Consortium for the Indo-Gangetic Plains; International Maize and Wheat Improvement Centre: New Delhi, India, 2003; p. 305. 
95. Bhattacharyya, R.; Das, T.K.; Pramanik, P.; Ganeshan, V.; Saad, A.A.; Sharma, A.R. Impacts of conservation agriculture on soil aggregation and aggregate-associated $\mathrm{N}$ under an irrigated agroecosystem of the Indo-Gangetic Plains. Nutr. Cycl. Agro-Ecosyst. 2013, 96, 185-202. [CrossRef]

96. Kukal, S.S.; Yadav, S.; Humphreys, E.; Kaur, A.; Singh, Y.; Thaman, S.; Singh, B.; Timsina, J. Factors affecting irrigation water savings in raised beds in rice and wheat. Field Crop Res. 2010, 118, 43-50. [CrossRef]

97. Yadvinder-Singh; Brar, N.K.; Humphreys, E.; Bijay-Singh; Timsina, J. Yield and N use efficiency of permanent bed rice-wheat systems in north-western India: Effect of $\mathrm{N}$ fertilisation, mulching and crop establishment method. In Permanent Beds and Rice-residue Management for Rice-wheat Systems in the Indo-Gangetic Plains; Humphreys, E., Roth, C.H., Eds.; Punjab Agricultural University: Ludhiana, India, 2008; p. 127.

98. Singh, Y.; Humphreys, E.; Kukal, S.S.; Singh, B.; Kaur, A.; Thaman, S.; Prashar, A.; Yadav, S.; Timsina, J.; Dhillon, S.S.; et al. Crop performance in permanent raised bed rice-wheat cropping system in Punjab, India. Field Crop Res. 2009, 110, 1-20. [CrossRef]

99. FAO. Should it be Watershed Management? Available online: fao.org/ag/agl/watershed/watershed/ papers/papercas/paperen/case12ec.pdf (accessed on 15 June 2016).

100. Erenstein, O.; Laxmi, V. Zero tillage impacts in India's rice-wheat systems: A review. Soil Tillage Res. 2008, 100, 1-14. [CrossRef]

101. Corbeels, M.; de Graaff, J.; Ndah, T.H.; Penot, E.; Baudron, F.; Naudin, K.; Andrieu, N.; Chirat, G.; Schuler, J.; Nyagumbo, I.; et al. Understanding the impact and adoption of conservation agriculture in Africa: A multi-scale analysis. Agric. Ecosyst. Environ. 2014, 187, 155-170. [CrossRef]

102. Pannell, D.J.; Llewellyn, R.S.; Corbeels, M. The farm-level economics of conservation agriculture for resource-poor farmers. Agric. Ecosyst. Environ. 2014, 187, 52-64. [CrossRef]

103. Joshi, P.K.; Tewari, L.; Jha, A.K.; Shiyani, R.L. Meta-analysis to assess impact of watershed. Available online: http://www.iwmi.cgiar.org/assessment/files_new/publications/CA\%20Research\%20Reports / CARR8_001.pdf (accessed on 16 June 2016).

104. National Bureau of Soil Survey and Land Use Planning (NBSS\&LUP) Vision, 2030, ICAR, NBSS\&LUP, Nagpur. Available online: http:/ / en.calameo.com/read/0025605141f057d8f219b (accessed on 16 April 2016).

105. Brouwer, F.; Riksen, M.; de Graaff, J. Soil Conservation Policy Measures to Control Wind Erosion in Northwestern Europe. Available online: http://www2.geog.ucl.ac.uk/weels/final_report/section_6.pdf (accessed on 15 June 2016).

106. Joshi, P.K.; Pangare, V.; Shiferaw, B.; Wani, S.P.; Bouma, J.; Scott, C. Socioeconomic and Policy Research on Watershed Management in India: Synthesis of Past Experiences and Needs for Future Research; Global Theme on Agroecosystems Report No.7; International Crops Research Institute for the Semi-Arid Tropics: Patancheru, India, 2004; p. 88.

107. Joshi, P.K.; Wani, S.P.; Chode, V.K.; Foster, J. Farmers Perception of Land Degradation. Presented at the Workshop on Institutions for Greater Impact of Technologies; National Centre for Agricultural Economics and Policy Research: New Delhi, India, 1996.

108. Singh, P.; Aggarwal, P.K.; Bhatia, V.S.; Murty, M.V.R.; Pala, M.; Owens, T.; Benli, B.; Rao, K.P.C.; Wani, S.P. Yield gap analysis: Modeling of achievable yields at farm level. In Rainfed Agriculture: Unlocking the Potential; Wani, S.P., Wani, S.P., Rockström, J., Oweis, T., Eds.; CAB Int.: Wallingford, UK, 2009; pp. 81-123.

109. Mishra, P.K.; Tripathi, K.P. Soil and water conservation research for land management in India. Indian J. Dryland Agric. Res. Dev. 2013, 28, 1-18.

110. Kale, S.R.; Salvi, V.G.; Varade, P.A. Runoff and soil loss as affected by different soil conservation measures under Eleusine coracana (Ragi) in lateritic soils. West coast Konkan Region (MH) India. India J. Soil Conserv. 1993, 21, 11-15.

111. Gund, M.; Durgude, A.G. Influence of contour and subabul live bunds on runoff, soil loss and yield of Pearl millet + Pigeonpea intercropping. Indian J. Soil Conserv. 1995, 23, 171-173.

112. Selveraju, R.; Ramaswami, C. Influence of fallowing and seasonal land configuration on growth and yield of sorghum (sorghum bicolor) + pigeonpea (Cajanus cajan) intercropping in Vertisols under varying seasonal precipitation. Indian J. Agron. 1997, 42, 396-400.

113. Belguami, M.K.; Basavaraja, H.; Radder, G.D.; Itnal, C.J. Economic evaluation of soil conservation structures in the Vertisols of the northern dry zone of Karnataka. Indian J. Soil Conserv. 1994, 22, 78-82. 
114. Sharma, K.L.; Vittal, K.P.R.; Srinivas, K.; Venkateswarlu, B.; Neelaveni, K. Prospects of organic farming in dryland agriculture. In Fifty Years of Dryland Agricultural Research in India; Singh, H.P., Ramakrishna, Y.S., Sharma, K.L., Venkateswarlu, B., Eds.; Central Research Institute for Dryland Agriculture: Santoshnagar, India, 1999; pp. 369-378.

115. Tejwani, K.G.; Gupta, S.K.; Mathur, H.N. Soil and Water Conservation Research; ICAR: New Delhi, India, 1975.

116. Joseph, S.; Manoj, M. Conservation measures for agricultural lands. Indian J. Soil Conserv. 1989, 17, 1-5.

117. Velayautham, K.; Rajendran, P.; Krishnaswamy, S. Field evaluation of in situ moisture conservation practice. Madras Agric. J. 1997, 84, 81-82.

118. Mishra, P.K.; Dash, S.K.; Behera, B.D.; Sahu, D. Evaluation of vegetative barriers for soil moisture conservation and sustained land productivity. Indian J. Soil Conserv. 1999, 27, 177-179.

119. Krishnegowda, K.T.; Krishnappa, A.M.; Panduranga, P.; Hedge, B.R. Live bunds for soil moisture conservation under dryland conditions. In Proceedings of International Symposium on Water Erosion Sediment and Resource Conservation, Dehradun, India, 9-13 October 1990; Post Symposium Proceedings. CSWCRTI: Dehradun, India, 1990.

120. Sur, H.S.; Sandhu, I.S. Effect on different grass barriers on runoff, sediment loss and biomass production in foothills of Shiwaliks. In Proceedings of the Abstracts of the 8th International Soil Conservation Organization Conference ISCO Conference, New Delhi, India, 4-8 December 1994; pp. 218-221.

121. Wani, S.P.; Kumar, M.S. On-farm generation of N-rich organic material. In A Training Manual on Integrated Management of Watersheds; Wani, S.P., Pathak, P., Rego, T.J., Eds.; ICRISAT: Patancheru, India, 2002; p. 30.

122. CRIDA. Central Research Institute for Dryland Agriculture. CRIDA Perspective Plan-Vision 2020; CRIDA: Hyderabad, India, 1997.

123. Sharda, V.N.; Dogra, P.; Prakash, C. Assessment of production losses due to water erosion in rainfed areas of India. Indian J. Soil Water Conserv. 2010, 65, 79-91. [CrossRef]

124. Katyal, J.C.; Singh, R.P.; Sharma, S.; Das, S.K.; Padmanabhan, M.V.; Mishra, P.K. Field Manual on Watershed Management (Revised and Enlarged Edition); Central Research Institute for Dryland Agriculture: Hyderabad, India, 1995; p. 223.

125. El-Swaify, S.A.; Pathak, P.; Rego, T.J.; Singh, S. Soil management for optimized productivity under rainfed conditions in the semi-arid tropics. Adv. Soil Sci. 1985, 1, 1-64.

126. Sharma, N.K.; Tripathi, K.P. Rainfall variation and its effect on $C$ and $P$ factor of Universal soil Loss Equation-A Review; Melkania, U., Prasad, H.J.S., Prasad, J., Eds.; G.B. Pant University of Agriculture and Technology: Pantnagar, India, 2007; p. 132.

127. Mandal, D.; Sharda, V.N. Assessment of permissible soil loss in India employing a quantitative bio-physical model. Curr. Sci. 2011, 100, 383-390.

128. Prakash, A.K.; Muralikrishna, I.V.; Mishra, P.K.; Chalam, R.V.R.K. Deciding alternative land use options in a watershed using GIS. J. Irrig. Drain. Eng. 2007, 133, 162-174. [CrossRef]

129. Suresh, K.; Palanisami, D.K. An economic inquiry into collective action and household behaviour in watershed management. Indian J. Agric. Econ. 2009, 64, 108-123.

130. Chennappa, T.C. Prediction models for runoff and soil loss from small agricultural watersheds. In Soil and Water Conservation, Challenges and Opportunities; Proceedings of the 8th ISCO International Soil Conservation Conference, New Delhi, India, 4-8 December 1994; Bhushan, L.S., Abrol, I.P., Ram Mohan Rao, M.S., Eds.; Indian Association of Soil \& Water Conservationists: Dehradun, India, 1994; pp. 683-691.

131. Sahoo, D.C.; Madhu, M.; Sharda, V.N.; Sikka, A.K. Runoff and soil loss behaviour with different conservation practices under new tea plantation in the Nilgiris. Indian J. Soil Conserv. 2011, 39, 207-211.

132. Joy, K.J. Watershed Development Review: Issues and Prospects; Centre for Interdisciplinary Studies in Environment and Development (CISED): Bangalore, India, 2003.

133. GoK, Government of Karnataka. Soil and Moisture Conservation Activities. A Study on Impacts and Sustainability; Sujala Watershed Project; Watershed Development Department, Government of Karnataka: Bangalore, India, 2008.

134. Sharma, A.R. Agronomic practices for increasing nitrogen use efficiency and productivity of flood-prone lowland rice in eastern India. Fertil. News 2002, 47, 27-44.

135. Kerr, J.; Pangare, G.; Pangare, V.; George, P.J. An Evaluation of Dryland Watershed Development in India; EPTD Discussion Paper 68; International Food Policy Research Institute: Washington, DC, USA, 2000. 
136. Shah, A. Watershed development programmes in India-Emerging issues for environment-development perspectives. Econ. Polit. Wkly. 1998, 33, A66-A80.

137. Reddy, V.; Ratna, M.; Reddy, G.; Oliver, S.; Springate-Baginski, O. Watershed Development and Livelihood Security: An Assessment of Linkages and Impact in Andhra Pradesh, India; Draft Report; Centre for Economic and Social Studies: Hyderabad, India, 2001.

138. Batchelor, C.; Singh, A.; Rama Mohan Rao, M.S.; Butterworth, J. Mitigating the potential unintended impacts of water harvesting. In Presented at the IWRA International Regional Symposium on Water for Human Survival, New Delhi, India, 26-29 November 2002; International Water Resources Association: New Delhi, India, 2002.

139. Kannan, K.; Srivastava, R.C.S.; Mohanty, M.; Sahoo, N. Strategies for adoption of crop production practices in Watershed Management Programmes. Indian J. Soil Conserv. 2004, 32, 225-227.

140. Karanth, G.K.; Anil, A. Participative Integrated Development of Watershed (PIDOW); Report of Participatory Impact Assessment; Swiss Agency for Development and Co-operation: New Delhi, India, 2001.

141. Kerr, J.M. Watershed development, environmental services, and poverty alleviation in India. World Dev. 2002, 30, 1387-1400. [CrossRef]

142. Anonymous. Study Report on Watershed Development; Kalpataru Research Foundation: Mumbai, India, 2001.

143. Rao, K.V.G.K.; Biswas, C.R.; Bandyopadhyay, A.K. Developing Suitable Methods to Store Rain Water and Its Use for Irrigation in Winter; Annual Report; Central Soil Salinity Research Institute: Karnal, India, 1981; pp. 190-191.

144. CSSRI, NAIP. Final Report of NAIP sub-Project on: Strategies for Sustainable Management of Degraded Coastal Land and Water for Enhancing Livelihood Security of Farming Communities (Component 3, GEF Funded); Burnan, D., Mandal, S., Mahanta, K.K., Eds.; Central Soil Salinity Research Institute, Regional Research Station (CSSRI, RRS): Canning Town, India, 2014; p. 104.

145. Burman, D.; Bandyopadhyay, B.K.; Mandal, S.; Mandal, U.K.; Mahanta, K.K.; Sarangi, S.K.; Maji, B.; Rout, S.; Bal, A.R.; Gupta, S.K.; et al. Land Shaping-A Unique Technology for Improving Productivity of Coastal Land; Bulletin No. CSSRI/Canning Town/Bulletin/2013/02; Central Soil Salinity Research Institute, Regional Research Station: Canning Town, India, 2013; p. 38.

146. Mandal, U.K.; Sharma, K.L.; Kausalya, R.; Adake, R.V. Soil moisture availability in rainfed agro-ecosystems in semiarid tropics. In Climate Change and Agriculture; Bhattacharyya, T., Pal, D.K., Sarkar, D., Wani, S.P., Eds.; Studium Press Pvt. Ltd.: New Delhi, India, 2013.

147. Kalla, J.C. Statistical evaluation of fuel yield and morphological variates for some promising energy plantation tree species in western Rajasthan. Ann. Arid Zone 1977, 16, 117-126.

148. Gupta, R.P.; Kumar, S.; Singh, T. Soil Management to Increase Crop Production; ICAR: New Delhi, India, 1984.

149. Soni, M.L.; Yadava, N.D.; Beniwal, R.K.; Singh, J.P.; Birbal, S.K. Grass based strip cropping systems for controlling soil erosion and enhancing system productivity under drought situations of arid western Rajasthan. Int. J. Agric. Stat. Sci. 2013, 9, 685-692.

(C) 2016 by the authors; licensee MDPI, Basel, Switzerland. This article is an open access article distributed under the terms and conditions of the Creative Commons Attribution (CC-BY) license (http://creativecommons.org/licenses/by/4.0/). 